\title{
An Ethno Botanical Review on Medicinal Plants Used for the Management of Hypertension
}

\author{
Meresa A $^{*}$, Fekadu N, Degu S, Tadele A and Geleta B
}

Directorate of Traditional and Modern Medicine Research, Ethiopian Public Health Institute, Addis Ababa, Ethiopia

*Corresponding author: Meresa A, Directorate of Traditional and Modern Medicine Research, Ethiopian Public Health Institute, P.O. Box 1242, Addis Ababa, Ethiopia, E-mail: asfawmeresa03@gmail.com

Received date: January 10, 2017; Accepted date: February 01, 2017; Published date: February 08, 2017

Copyright: (C) 2017 Meresa A, et al. This is an open-access article distributed under the terms of the Creative Commons Attribution License, which permits unrestricted use, distribution, and reproduction in any medium, provided the original author and source are credited.

\begin{abstract}
Hypertension has become one of the most principal growing health problems in developing countries, and is an important cause of cardiovascular death in the world. It is also called the silent killer as it usually shows no direct symptoms and many people die of the disease without understanding its. Despite their availability and effectiveness, the conventional drugs used for the treatment of hypertension have caused adverse side effects and increased the risks of developing new diseases. Herbal medicines, therefore, are gaining great demand and more importance in the treatment of hypertension because of their wide biological and medicinal activities, higher safety margins and lesser cost. Accordingly this review article mainly focuses on medicinal plants used for the management of hypertension in Ethiopia and provides a list of sixty six anti-hypertensive plants obtained from various sources. Furthermore, the review briefly describes the photochemistry and pharmacological properties of Moringa stenopetala, Thymus serrulatus, Thymus schimperi, Syzygium guineense and Calpurnea aurea. The purpose of this review is to create baseline data for future pharmacological and phytochemical investigations involving traditional medicinal plants used for treating hypertension and to preserve the traditional knowledge.
\end{abstract}

Keywords: Hypertension; Medicinal plants; Antihypertensive drugs; Phytochemicals; Efficacy; Safety

\begin{abstract}
Abbreviations:
AU: African Union; HIV: Human Immunodeficiency Virus; CVD: Cardiovascular Disease; DBP: Diastolic Blood Pressure; MABP: Mean Arterial Blood Pressure; SBP: Systolic Blood Pressure; MoH: Ministry of Health; NCD: Non-Communicable Disease; WHO: World Health Organization; mM: Millimolar; SSA: Sub-Saharan African; WBCs: White Blood Cells; KCl: Potassium Chloride; GC: Gas Chromatography; GC-MS: Gas Chromatography Mass Spectrometer; ALT: Alanine Amino Transferase, AST: Aspartate Transaminase; ALP: Alkaline Phosphatase; GGT: Gamma-Glutamyl Transferase; BUN: Blood Urea Nitrogen
\end{abstract}

\section{Introduction}

The world population has encountered growing burdens of NonCommunicable Diseases (NCDs) which result in economic as well as a serious current and long term health problems [1,2]. The prevalence of Cardiovascular Disorders (CVDs) has been increasing across many regions of the world which are experiencing a rapid health transition [3]. CVDs account approximately for one-third of total deaths a year [4]. Several studies indicate that CVDs are responsible for almost $80 \%$ of the global burden of diseases in low and middle income countries [5-7] and it is predicted to be the leading cause of mortality and disability by 2020 mainly because of its rise in the future in these countries [5]. Globally, the major risk factors for CVD include tobacco use, high blood pressure, high blood glucose, lipid abnormality, obesity and physical inactivity. In Sub-Saharan Africa (SSA), the leading risk factors were accountable to $54 \%$ mortality and $45 \%$ of the burden of the disease in $2001[5,6]$.
Hypertension is one of the major risk factor for CVD throughout the world [8]. It contributes to myocardial infarction, cerebrovascular accidents, congestive heart failure, peripheral vascular insufficiency, coronary artery disease, stroke and premature mortality [4-11]. Hypertension has been identified as the leading risk factor for mortality and ranked third as a cause of disability-adjusted life years [12]. Hypertension has become a growing common health burden globally because of the rising prevalence of the contributing risk factors such as obesity, physical inactivity and unhealthy diet [13]. The disease affects both sexes and increases as function of age in both sexes [11-15]. Complications of hypertension account for 9.4 million deaths worldwide. Hypertension is responsible for at least $45 \%$ for deaths due to heart disease and $51 \%$ of deaths due to stroke [6]. Hypertension has been reported to be the fourth contributor to premature death in the developed countries and the seventh in developing countries [16].

The prevalence of hypertension is higher in low and middle income countries than higher income countries. Besides this, the number of people affected also exceeds those of high income countries because of the high proportion of population living in these regions and their weak health system [6]. According to the World Health Organization, about one third of the world's population suffers from hypertension and the incidence has been increasing at a rapid rate due to life style modification [17].

More than a quarter of the world's adult population is hypertensive, this proportion is expected to increase in the coming years and subSaharan Africa is no exception to this trend. According to epidemiological projections in 2025, 29.2\% of adults worldwide will suffer from hypertension whose three-quarters will live in developing countries. The total number of adults with hypertension in many African countries has been estimated to be over $40 \%$ in recent years [6-19]. Population growth, ageing and behavioural risk factors, such as unhealthy diet, harmful use of alcohol, lack of physical activity, excess 
weight and exposure to persistent stress are contributing factors for the increasing prevalence of hypertension $[6,20]$. The prevalence of the disease and its related conditions has been recognized to be increasing in the developing countries [21].

\section{Epidemiological Status of Hypertension in Ethiopia}

Ethiopian has been facing the consequences of epidemiologic, demographic, economic and nutrition transitions which favour the chronic diseases epidemic. Some of the major contributing factors for the prevalence of NCDs in Ethiopia include the adoption of Western lifestyle in urban areas particularly a more sedentary way of life, increased cigarette smoking, employment in manufacturing industries, greater stress, and consumption of more refined food and increasing life expectancy in cities [22]. In Ethiopia, there is a lack of reliable CVD mortality and morbidity data which is due to the nature of the diseases and the less attention given to chronic diseases and lack of nationwide survey on chronic diseases [5,22].

Although there was no well documented data on prevalence of hypertension at national level, few studies conducted at different regions of Ethiopia and at the capital city reported an increased prevalence of hypertension [16-24]. One earlier study showed that the prevalence of hypertension in rural villages of Ethiopia was 1.8\% [25]. Another study conducted on the rural and semi-urban residents of Butajira also showed that $12.3 \%$ of men and $8.2 \%$ of women had hypertension [26]. Furthermore, a population based study in Addis Ababa in the year 2006 found that the prevalence of high blood pressure or reported use of anti-hypertensive medication was around $32 \%$ males and $29 \%$ females [23]. A study has recently indicated that the prevalence of hypertension and diabetes among Ethiopian adults is $14.9 \%$ in women and $22 \%$ in men [27].

Recent evidences indicate that hypertension and raised blood pressure are increasing partly because of the increase in risk factors including smoking, obesity, and harmful use of alcohol and lack of exercise [28]. Moreover, according to the health and health-related indicators of $\mathrm{MoH}$, hypertension was ranked as the seventh and sixth leading cause of death in the country in 2001 and 2006 respectively $[29,30]$. Therefore, the need to control hypertension is very crucial as its prevalence and severity has been escalating across the developing countries, including Ethiopia.

\section{Management of hypertension with conventional medicines}

A number of synthetic anti-hypertensive drugs have become available in the market through research owing to the rising prevalence and severity of hypertension throughout the world [11,31]. Despite their availability, people who live in many developing countries are forced to frequently recourse to and rely on traditional medicine which mainly uses medicinal plants due to their low socio-economic levels, the high cost and harmful side effects of conventional medicines [19-33].

Treatment of hypertension with anti-hypertensive synthetic drugs are associated with side effects such as dizziness, nausea, stomach problems, impotence, fatigue, insomnia, loss of appetite and many others [34-36]. Moreover, they increase the risk of developing new diseases which worsen the situation and result in suboptimal control of high blood pressure [37]. As a result, many scientific studies suggest different life style changes and use of appropriate herbal medicines in the treatment of high blood pressure due to the various side effects that come with the use of different types of conventional anti-hypertensive drugs $[35,36]$.

\section{The role of herbal medicines in management of hypertension}

Traditional medicines had been used to treat various health problems for thousands of years in many parts of the world and are still utilized by the developing countries. The use of herbal medicine has been on the increase in many developing countries [38]. The developed countries have also shown an increased interest and use of herbal drugs due to public dissatisfaction with the cost of prescription drugs and interest in returning in to natural remedies [37,39]. Herbal medicines have significantly played a great role and contributed immensely to the development of cardiovascular research. For the treatment of cardiovascular diseases, herbal medicines have been used in patients with hypertension, congestive heart failure, angina pectoris, atherosclerosis, cerebral insufficiency, and arrhythmia [40].

Up to $90 \%$ of Ethiopian population use traditional medicine [41]. This is primarily due to the cultural acceptability of healers and local pharmacopeia, the relatively low cost of traditional medicine and poor access to modern health facilities [38-43]. The use of medicinal plants for the treatment of hypertension is very common among nonindustrialized nations due to their easy availability and low cost than novel pharmaceuticals [44]. Numerous drugs from plants such as root of Solanum sisymbriifolium, Cocos nucifera Linn and Hibiscus sabdariffa have also been used in the treatment of hypertension [45].

Herbal medicines have been gaining more importance in the treatment of hypertension in recent years and are in great demand both in the developed and developing countries for primary health care because of their wide biological and medicinal activities ease of availability, higher safety margins and lesser cost [21,31]. With the increasing trend of hypertension prevalence and burden as well as serious adverse side effects, treatment failure, absence of cost effective mono therapeutic anti-hypertensive drugs in use and their serious adverse side effects, herbal plants would have been important and sustainable alternative sources of treatment for high blood pressure $[21,46]$.

Hence, in order to overcome the rising prevalence and severity of hypertension and its associated cardiovascular risk factors, a consolidated scientific investigation should be adopted by the developing countries for the search of novel, safe and effective compounds from plant sources. The current review provides a list of medicinal plants used to treat high blood pressure in Ethiopia. In addition to listing the anti-hypertensive medicinal plants, it also made a brief review on the phytochemistry, pharmacological activities, safety, and toxicity studies of five commonly used antihypertensive plants.

\section{Moringa stenopetala: Family: Moringaceae; Local name: Shiferaw or Haleko}

\section{Part used: leaf}

Phytochemistry: Phytochemical screening tests performed on the crude aqueous leaf extracts of Moringa stenopetala confirm the presence of alkaloids, saponins, polyphenols, flavonoids, coumarins, terpenoids, anthraquinones, tannins, phytosterols and cardiac glycosides and the presence of all the secondary metabolites except saponnins in $70 \%$ alcohol fractions [7]. A preliminary phytochemical analysis carried out for butanol fraction of solvent-solvent separate and column chromatographic fractions of Moringa stenopetala leaves also 
proved the presence of flavonoids, phenolic compounds and phenolic glycosides [47].

Pharmacological properties, antihypertensive activity: The Various parts of the Moringa stenopetala are claimed to contain disease preventing chemicals [48]. Moringa stenopetalais is traditionally used for the treatment of various ailments such as malaria, hypertension, asthma, diabetes, stomach pain [49]. People with high blood pressure boil the leaves and drink the water to get relief from their ailment [48].

Several scientific studies have also confirmed that the various parts of the plant possess anti-malarial, antileishmenial and anti-fertility [50], hypotensive [40], anti-hypertensive [7], vasodilatory [51], hypoglycemic [52], and anti-diabetic effects [47,53].

A study on antihypertensive and anti-hyperlipidemia effect of Moringa stenopetala leaves in experimental rats revealed that the aqueous crude extract and $70 \%$ ethanol fraction significantly prevented blood pressure increment in a dose-dependent manner and suppressed increment in cholesterol, glucose and triglycerides. Similarly, the crude aqueous leaf extract of Moringa stenopetala caused a significant reduction in SBP, DBP and MABP at doses of 10, 20, 30 and $40 \mathrm{mg} / \mathrm{kg}$ in normotensive anaesthetized guinea pigs [40]. In addition, the ethanol and aqueous crude extracts has shown a dose dependent relaxation effect at doses $1.25,2.5,5.0$ and $10 \mathrm{mg} / \mathrm{ml}$ and the greater percent relaxant effect was shown on against $(80 \mathrm{mM})$ potassium chloride and $(1 \mu \mathrm{M})$ epinephrine pre-contracted isolated whole spirally-cut strips thoracic of guinea pigs [51]. According to Geleta et al. [54], the diuretic activity of hydro-ethanol extract of Moringa stenopetala leaves was evaluated in Swiss albino mice. The hydroethanol extract of the plant has shown a significant urine output at all doses and significantly increased the excretion of $\mathrm{Na}^{+}$and $\mathrm{Cl}^{-}$at higher doses [54]. These pharmacological activities might be attributed to presence of different phytochemical constituents found in the plant extract, especially glycosides and alkaloids $[7,51]$.

Safety and toxicity: Ghebreselassie et al. evaluated the effects of aqueous leaf extract of Moringa stenopetala on blood parameters, and the histopathology of liver and kidney in experimental mice [55]. Subchronic toxicity testing of this study revealed that no significant changes in the weight and in the histopathology of liver and kidney were detected in the animals treated with aqueous extract of the plant in comparison with the controls [55]. Whereas, the aqueous and ethanol crude extracts showed a rise in liver function indicators with no effect on kidney function indicators compared with normal control [56]. Similarly, the aqueous leaf extract of $M$. stenopetala caused a significant decrease in body weight of mice treated with $900 \mathrm{mg} / \mathrm{kg}$ of dose as compared with the controls. The acute toxic effect of n-butanol fraction of the leaves of $M$. stenopetala in experimental mice was evaluated [57]. The results of this study illustrated that no behavioral, gross pathology and body weight of the experimental mice treated with up to $5000 \mathrm{mg} / \mathrm{kg}$ doses of the fraction were seen in comparison with the control groups. This suggests the safety of the fraction.

Musa et al. also investigated the biochemical and hematological activity of n-butanol fraction of the leaves of $M$. stenopetalain experimental Rats [49]. The results of this sub chronic toxicity study indicated that $\mathrm{n}$-butanol fraction of the leaves of $M$. stenopetala produced no significant difference on the biochemical and hematological parameters (except blood glucose) of the treated rats from the control groups and laid within the reference range at two doses administration (500 and $1000 \mathrm{mg} / \mathrm{kg}$ ) of the fraction [49].
Another recent study by Geleta et al. on the acute toxic effect of the $\mathrm{n}$-butanol fraction of the leaves of $M$. stenopetala in experimental mice also suggested that the n-butanol fraction of the leaves of $M$. stenopetala did not cause any mortality up to $5000 \mathrm{mg} / \mathrm{kg}$ doses of the fraction [56]. Similarly, no body weight reduction, visible signs of toxicity and gross pathological alteration (colour, size and texture) were observed. Furthermore, the study results showed that the fraction did not produce adverse effects on hematological and biochemical parameters of the blood [56].

The effect of various solvent crude extracts and fractions of $M$. stenopetala on liver and kidney of experimental rats was toxicologically evaluated for sub-acute toxicity study. As compared with the normal control, both the crude extracts and solvent fractions at 250,500 and $1000 \mathrm{mg} / \mathrm{kg}$ doses administration caused to increase ALT, AST, ALP and GGT, but produced no significant rise in the plasma level of BUN and creatinine in the treatment rats. However, repeated oral daily administration has revealed potential damage to the liver in a dose dependent manner but not to the kidney. No signs of toxicity, mortality and gross physical and behavioural changes were observed with close follow up after $4 \mathrm{~h}, 24 \mathrm{~h} 14$ days of extract administration, at a dose of $5000 \mathrm{mg} / \mathrm{kg}$ [56].

\section{Thymus serrulatus: Family: Lamiaceae; Local name: Tossign}

\section{Parts used: leaf}

Phytochemistry: Different studies reported that the presence of $\alpha$ pinene, $\alpha$-terpinene, $\gamma$-terpinene, $\mathrm{p}$-cymene, carvacrol, thymol and linalool as the major constituents of the essential oil of Thymus serrulatus using GC-MS analysis [58]. Thymus extract as well as powdered leaves were also found to contain polyphenols, phytosterols, alkaloids, tannins, saponins, and withanoids [59].

Some of the chemical structures for potentially active compounds of thymus species in Ethiopia are shown below:

Pharmacological properties, anti-hypertensive activity: Thymus serrulatus is used as a spice and as culinary ingredient, food preservative and in aroma industries in Ethiopia. The leaf of this medicinal plant is utilized for the treatment of renal diseases, hypertension and Taenia captis [60]. The aqueous and methanol extract of Thymus serrulatus showed a significant spasmolytic activity using a charcoal meal test in mice [59]. In addition, the studies reported that the aqueous and methanol extracts of T. serrulatus have moderate diuretic activity. Whereas, the n-butanol fraction of aqueous crude extract revealed a comparable diuretic activity to standard drug, hydrochlorthiazide $[61,62]$.

The vasodilator effect of the aqueous leaf extract of $T$. serrulatus on isolated thoracic aorta rings pre contracted with $80 \mathrm{mM} \mathrm{KCl}$ solution was investigated. The results of this study revealed that a sequential administration of increasing concentration of the aqueous leaf extract this plant weakened the force of contractions induced with potassium chloride solution on thoracic aorta of Guinea pigs both in intact and removed endothelium. The greater percentage of relaxation was observed in intact endothelium than in denuded endothelium of the guinea pigs thoracic aorta at the same concentration of the extract [60]. This pharmacology activity might be attributed to the phytoconstituents found in the plant extract, majorly by alkaloids and phenols [59-62]. 

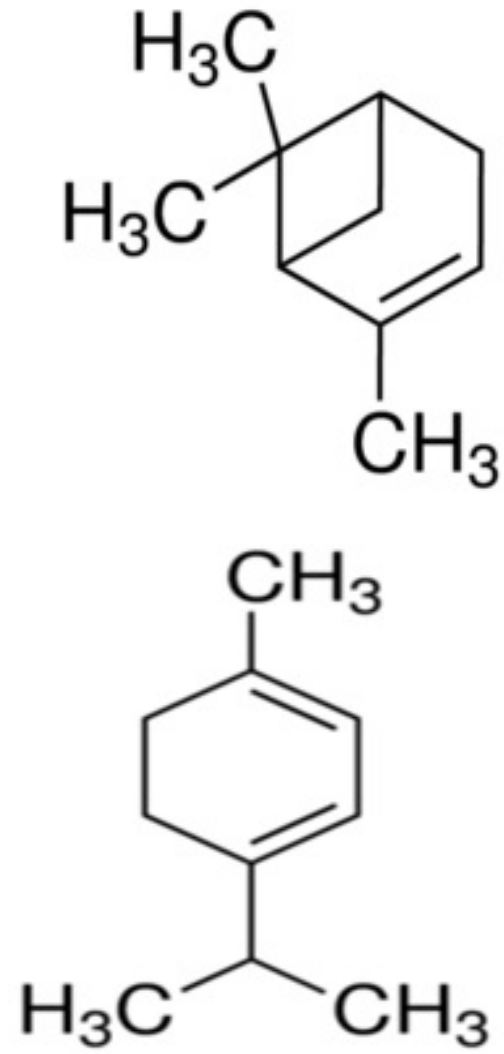

Alpha ( $\alpha$-pinene) Alpha-terpinene ( $\alpha$-terpiene)
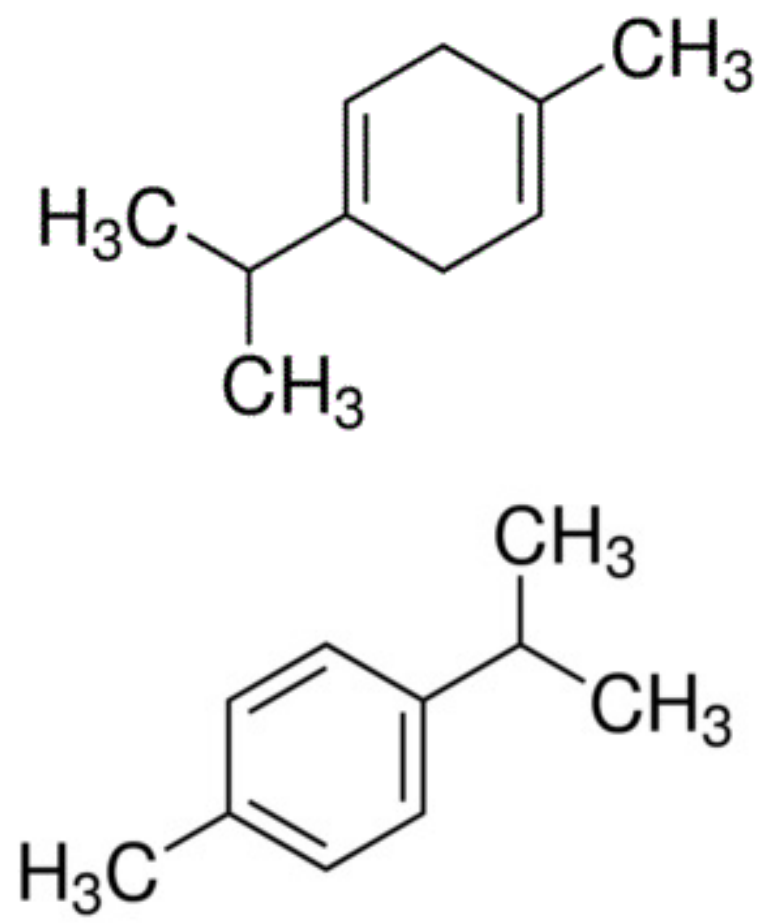<smiles>Cc1ccc(C(C)C)c(O)c1</smiles>

Thymol<smiles>Cc1ccc(C(C)C)cc1O</smiles>

Carvacrol
Safety and toxicity: The toxic effect of the aqueous leaf extract of $T$. serrulatus in experimental mice was investigated. In the acute toxicity study, the experimental mice received the extract up to $10,000 \mathrm{mg}$ doses per kg body weight. Intra-gastric administration of the extract in the mentioned dose caused no sign of morbidity and mortality during the period of the experiment. The experimental mice were given 200 and $600 \mathrm{mg} / \mathrm{kg}$ doses of the aqueous leaf extract at one day interval for ninety days in the sub chronic toxicity testing. The study results indicated that no significant changes were observed on the hematological parameters of both female and male mice and biochemical parameters of female mice. However, the plant extract at $200 \mathrm{mg} / \mathrm{kg}$ dose significantly increased the quantities of WBCs in experimental groups compared to the control groups. Similarly, the concentration level of BUN per urea was significantly decreased in the female mice by both doses of the plant extract compared to the control groups. The aqueous leaf extract of $T$. serrulatus did not reveal any significant change on the weight of liver and kidneys of male and female mice treated with doses of 200 and $600 \mathrm{mg} / \mathrm{kg}$ compared to the control groups. Gross pathologic examinations of internal organs of treated rat and mice also revealed no abnormal changes in texture, shape, size or color of liver and kidney and no sign of necrosis or lesion were observed [63].

\section{Thymus schimperi: Family: Lamiaceae; Common name: Tossign}

\section{Parts used: leaf}

Phytochemistry: Results of GC and GC-MS analysis revealed the presence of p-cymene, $\alpha$-terpiene, thymol and carvacrol as the main constituents of the essential oils of Thymus schimperi taken from four different regions of Ethiopia. Furthermore, phytochemical tests conducted on the crude extract and powdered plant leaves of Thymus schimperi for the major classes of secondary metabolites only confirmed the presence of phenols, tannins and, saponins which are responsible for the diuretic and anti-hypertensive activity of the plant $[64,65]$.

p-cymene $\gamma$-terpinene 
Medicinal properties, antihypertensive activity: Thymus schimperi, locally known as 'Tossign', mostly grows at altitude of 2250-4000 masl (afromantane and afro alpine vegetation zones [66]. In traditional medicine, Thymusspecies in Ethiopia are used to treat different illnesses like gonorrhea, cough and liver disease, renal diseases, stomach pain, hypertension, kidney problem and dermal fungi [67]. They have been reported to have anti-helminthic, antibacterial and fungicidal activities $[58,68]$.

The anti-hypertensive effect of the leaves of Thymus schimperi has recently been investigated [65]. The oral administration of aqueous extract of Thymus schimperi leaves and its essential oil distillate at doses of $(250,500,750$ and $1000 \mathrm{mg} / \mathrm{kg})$ and $(1$ and $1.5 \mathrm{ml} / \mathrm{kg})$ was respectively evaluated for their diuretic and anti-hypertensive activity against salt-sucrose induced hypertensive rats. The aqueous extract of Thymus schimperi leaves for all mentioned doses showed positive diuretic activity at $5 \mathrm{~h}$ and the two higher doses significantly increased $\mathrm{Na}+, \mathrm{K}^{+}$and $\mathrm{Cl}$-content of urine [65]. The pharmacological properties of Thymus schimperi might be attributed to presence of various phytochemical constituents in extract such as phenols and saponins [65].

Safety and toxicity: Results of acute toxicity testing showed that no clinical signs of toxicity mortality as well as behavioral changes were observed at the oral limit dose of $5000 \mathrm{mg} / \mathrm{kg}$ during the observation period [65]. In addition, acute toxicity study done by Debelo et al. [69] has shown that the extract did not reveal any signs of toxicity; hence the LD50 was suggested to be higher than $10,000 \mathrm{mg} / \mathrm{kg}$.

There was no significant change $(\mathrm{p}>0.05)$ in general body weight and most of evaluated hematological and biochemical parameters after 90 days of sub-chronic treatment at 200 and $600 \mathrm{mg} / \mathrm{kg}$. The kidneys and liver of treatment group appear normal in their texture, shape, size or color compared to the control group in gross and histopathological examination. However, the light microscopic examination reveals that there was localized mononuclear lymphocytic infiltration and mild blood congestion within the hepatic portal and central veins in liver at higher dose $(600 \mathrm{mg} / \mathrm{kg})$ [69].

\section{Syzygium guineense: Family: Myrtaceae; Local name: 'Baddeessaa' in Afaan Oromoo and 'Dokma' in Amharic}

\section{Parts used: leaf}

Phytochemistry: Preliminary phytochemical tests for the ethanolic leaf extract of Syzygium guineense confirmed the presence of cardiac glycosidic, saponins, flavonoids, tannins and carbohydrates [70]. Two different studies also revealed the presence of caryophylleneoxide

Medicinal properties, antihypertensive activity: Syzygium guineense, which belongs to the Family myrtaceae, is available in the altitude range of 2,300-2,700m above sea level. Its bark decoction was used for the treatment of diarrhea and the twigs and roots of this plant were also used for various stomach ailments. Various solvent extracts of different parts of the plant have shown to possess antibacterial and molluscidal activities. Methanol extract of $S$. guineense bark also produced sustained hypotension in anaesthetized rats with greater fall in blood pressure was in diastolic rather than in systolic blood pressure [73].
(7\%), d-cadinene (7.5\%), viridiflorol (7.5\%), epi- $\alpha$-cadinol (9.8\%), $\alpha$ cadinol $12.7 \%)$, cis-calamenen -10-ol (14\%), citronellyl pentanoate (15.2\%), $\beta$-caryophyllenr $(20.1 \%)$ and $\alpha$-humulene $(39.5 \%)$ in the essential oil of leaves of Syzygium guineense [71,72].<smiles>C=C1CCC2O[C@]2(C)CC[C@@H]2[C@@H]1CC2(C)C</smiles>

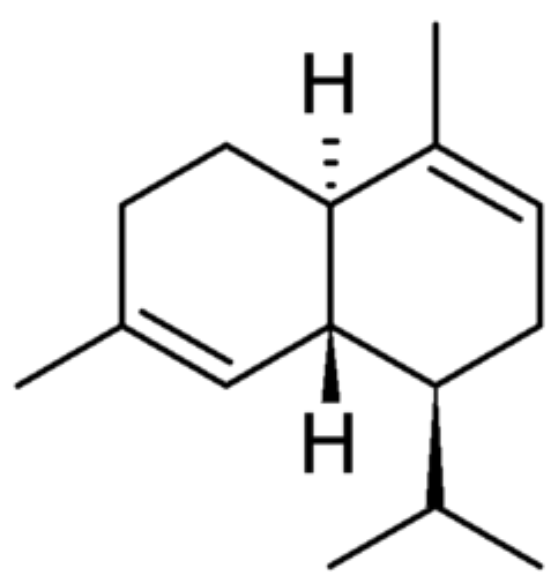

Caryophylleneoxide d-cadinene
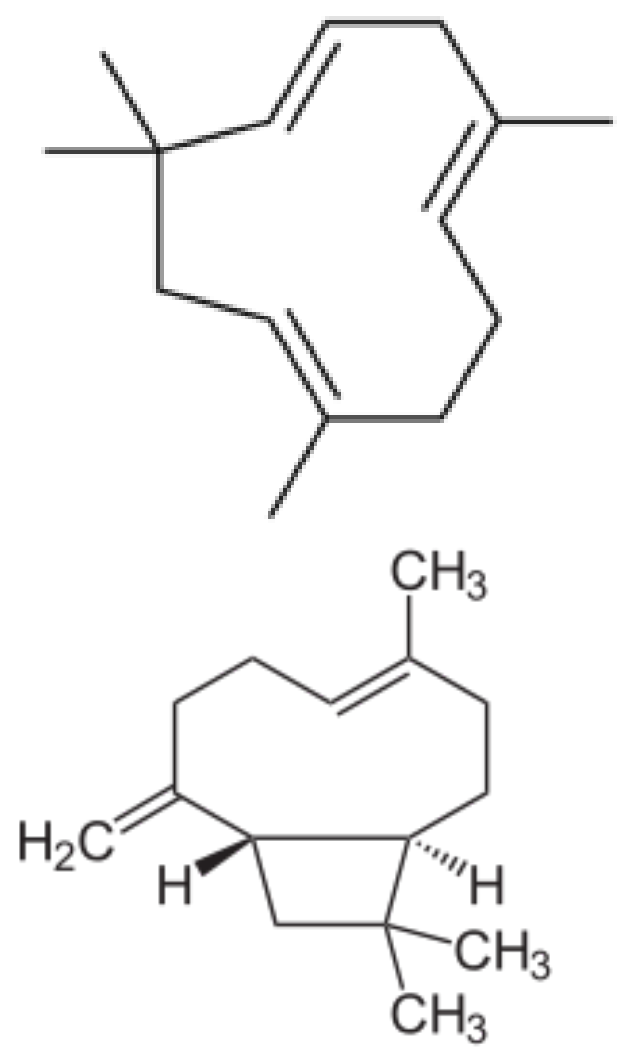

a-humulene $\beta$-caryophyllenr 
Many morphological parts of $S$. guineense have been traditionally utilized in the management of various ailments in many Ethiopian communities [32]. Several studies reported that various preparations of the parts of this plant have shown to possess anti-diarrheal and antidysentery, anti-hypertensive, anti-microbial, anti-malarial, antibacterial as well as hypotensive properties [32,74]. The antihypertensive effect of the hydro-methanol leaf extract of $S$. guineense at different doses in a 1-kidney 1-clip hypertensive rat model was evaluated for three consecutive days of treatment. The results of this study indicated that the hydro-methanol leaf extract of the plant caused a significant fall in SBP, DBP and MBP with increasing dose. Moreover, the aqueous-methanol leaf extract of $S$. guineense demonstrated a dose-dependent relaxation on the guinea pig isolated aorta pre contracted with $80 \mathrm{mM} \mathrm{KCl}$ solutions [32].

Safety and toxicity: The toxic effect of the hydro-methanol leaf extract of $S$. guineense was evaluated in rats. In the acute toxicity testing, group I and II treatment rats were orally given with 2000 and $5000 \mathrm{mg} / \mathrm{kg}$ respectively in single administration and the control group received distilled water. The results of this study concluded that the $80 \%$ methanol leaf extract of $S$. guineense is safe up to the highest second concentration as no toxicity signs and symptoms as well as mortality were seen in the treated rats in the given concentration levels. In the sub-acute toxicity test, group I and II treatment rats were orally administered respectively with $500 \mathrm{mg} / \mathrm{kg}$ and $1500 \mathrm{mg} / \mathrm{kg}$ doses of the hydro-methanol leaf extract of $S$. guineense. Results of this test revealed that the hydro-methanol leaf extract showed no significant difference in the hematological parameters as compared with the control groups. No significant difference in the body weight changes was observed at these doses [75].

\section{Calpurnea aurea: Family name-Fabaceae; Local name: 'chekata' in Afaan Oromoo and 'digita' in Amharic}

\section{Part(s) used: seed}

Phytochemistry: The result of preliminary phytochemical screening of powdered leaves of Calpurnia aurea showed the presence of several secondary metabolites including alkaloids, cardiac glycosides, flavonoids, phenols, phytosteriods, saponins, terpenoids and tannins using standard qualitative phytochemical screening test procedures [76,77].

Two novel alkaloids $3 \beta, 4 \alpha, 13 \alpha$-trihydroxylupanine and $3 \beta, 4 \alpha$ dihydroxy $13 a-O-(2$-pyrroly $1 \mathrm{c}$ arbonyl)-lupanine 16 (calpaurine) have been isolated from the leaves of Ethiopian $C$. aurea ssp-aurea. Two minor quinolizidine alkaloids, $4 \beta$-hydroxyl-13a-O- $(2$ 'pyrrolylcarbonyl)-lupanine (digittine) and $4 \beta, 13 \alpha$-dihydroxylupanine have also been detected in the leaves. The main pharmacologically active compound is assumed to be the alkaloid calpurmenin and its $13 \alpha$-(2'-pyrrolecarboxylic acid) ester. Two novel minor quinolizidine alkaloids 4 beta-hydroxy-13alpha-O-(2'-pyrrolylcarbonyl)-lupanine (digittine) and its amino alcohol, 4 beta, 13alpha-dihydroxylupanine, have been isolated from Ethiopian $C$. aurea ssp. aurea. The structures of these alkaloids were determined by chemical transformation and by means of spectroscopic techniques (UV, IR, CD, MS, (1) H-NMR and (13) C-NMR) including two dimensional NMR [78,79].

Chemical investigations of $C$. aurea have resulted in the isolation of a series of alkaloids, phenolic compounds, flavonoids, flavonols, and proanthocyanidins, which also founds in the genus Calpurnia [78]. Some of the chemical structures of the isolated compounds are clearly depicted below:
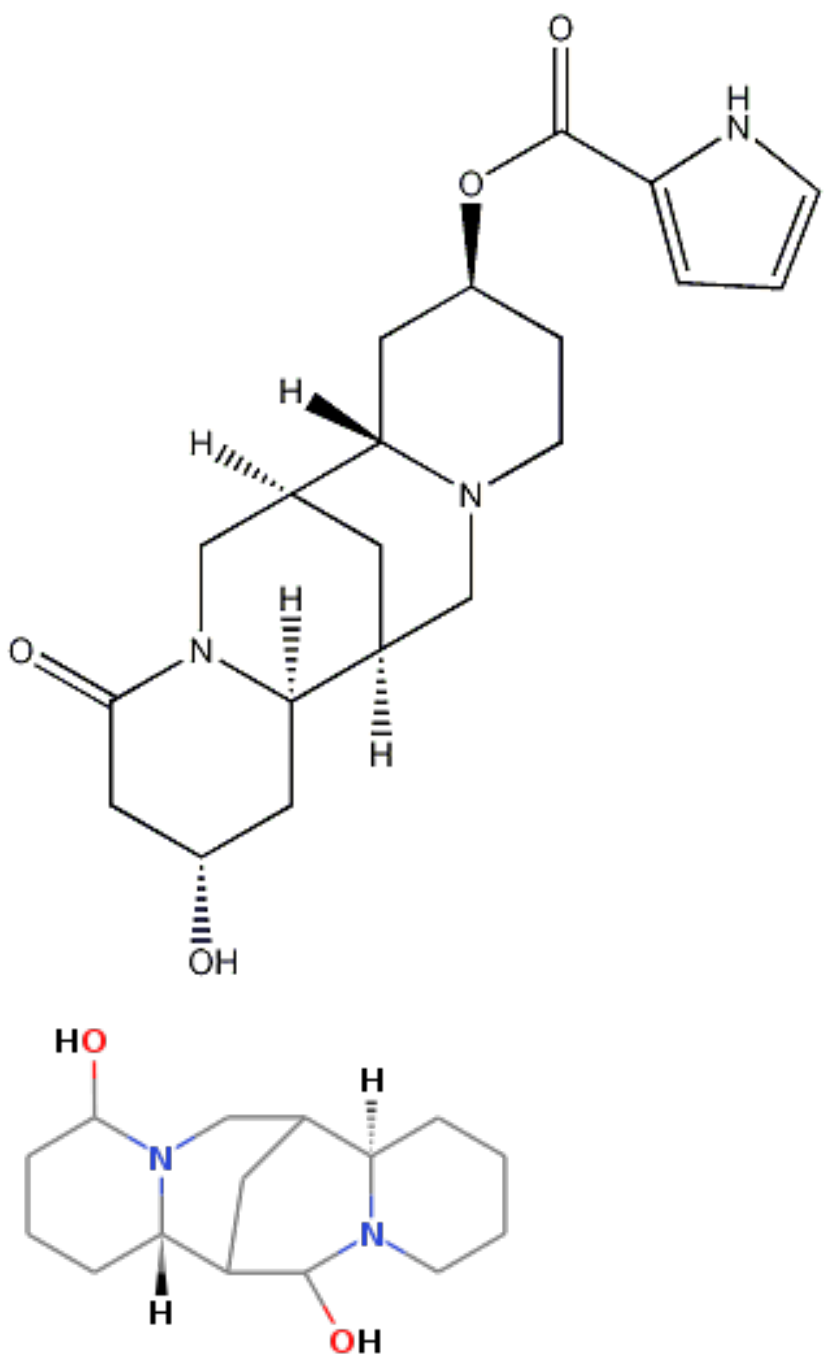

Digittine $4 \beta, 13 \alpha$-dihydroxylupanine 


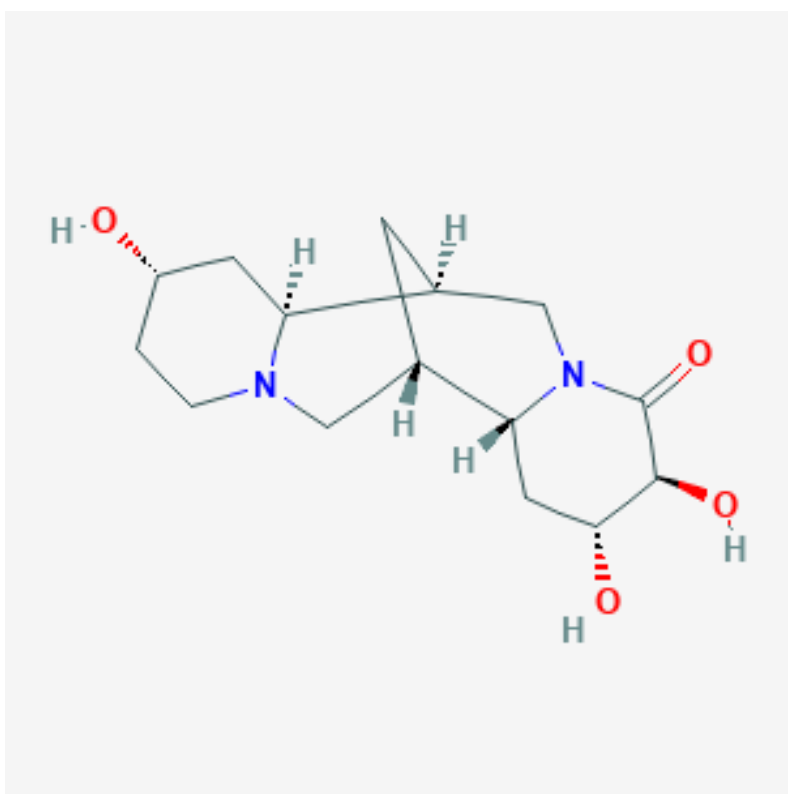

$3 \beta, 4 \alpha, 13 \alpha$-trihydroxylupanine

Apart from the quinolizidine alkaloids, the flavonoids vicenin-2 (6,8-di- $\beta$-D-glucopyranosyl-5,7,4'-trihydroxyflavone) [A], butin $\left(7,3^{\prime}\right.$, 4'trihydroxyflavanone $) \quad[\mathrm{B}] \quad$ and 3 '-hydroxydaidzein $\quad\left(7,3^{\prime}, 4^{\prime}-\right.$ trihydroxyisoflavone) [C] were isolated from the seeds of $C$. aurea, in keeping with flavonoids being the other major class of compounds consistently found in the Fabaceae [6].<smiles>O=c1cc(-c2ccc(O)cc2)oc2c([C@@H]3O[C@H](CO)[C@@H](O)[C@H](O)[C@H]3O)c(O)c([C@@H]3O[C@H](CO)[C@@H](O)[C@H](O)[C@H]3O)c(O)c12</smiles><smiles>O=C1CC(c2ccc(O)c(O)c2)Oc2cc(O)ccc21</smiles>

$[\mathrm{A}][\mathrm{B}]$

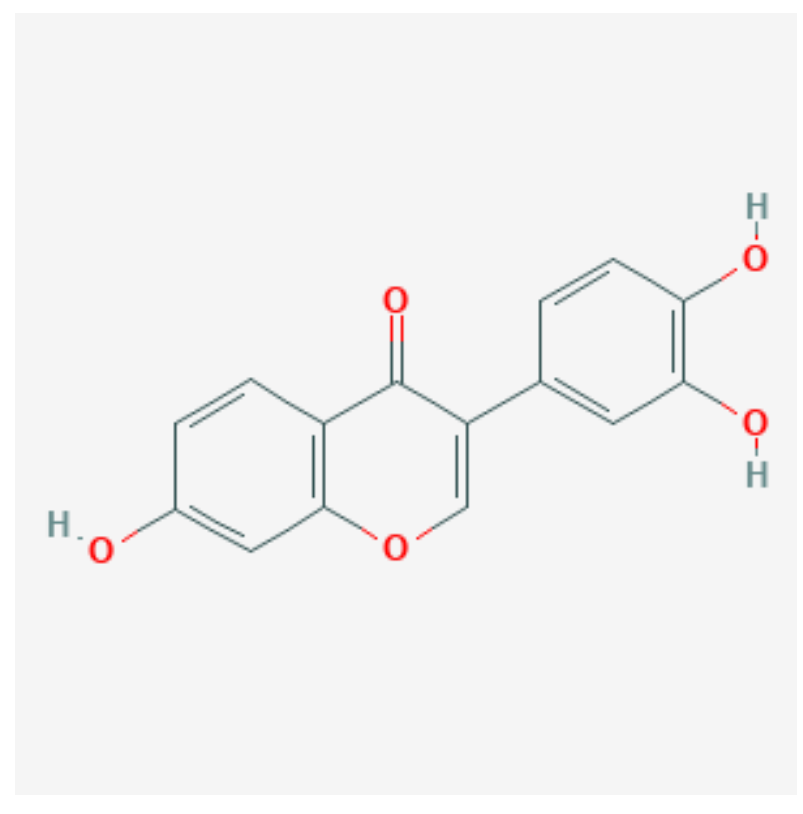

[C]

Pharmacological properties: In Ethiopia, traditionally, the leaves of C. aurea are used for the treatment of syphilis, malaria, rabies, diabetes, hypertension, diarrhoea, leishmaniasis, trachoma, elephantiasis, fungal diseases and different swellings, stomach-ache, bowel, and bladder disorders [77,79]. Its seed powder mixed with honey is also used to treat giardia and amoebiasis [80]. The roots of $C$. aurea is claimed to show activity against amoebiasis and giardiasis; the leaf in combination with the seed is utilized for treatment of diarrhea, rabies and diabetes; and the seed is used for treatment of hypertension [81].

Efficacy data: The $80 \%$ methanolic extract of the seeds of $C$. aurea have been tested for their in vivo and ex vivo antihypertensive activity. The crude extract caused a marked decrease in SBP, DBP and MABP at the doses of 15, 30 and $45 \mathrm{mg} / \mathrm{kg}$ in normotensive anaesthetized. The BP went down dose dependently and significantly in renal hypertensive rats, induced by renal ischemia. The extract produced $15.4 \%, 26.9 \%, 33.2 \%$ reduction in SBP at the respective doses of 15,30 and $45 \mathrm{mg} / \mathrm{kg}$. The extract also caused a dose-dependent relaxation of guinea pig aorta pre-contracted with $\mathrm{KCl}(80 \mathrm{mM})$, at a concentration of $5-250 \mathrm{mg} / \mathrm{ml}$, with a maximum relaxation of $92.1 \pm 0.72 \%(\mathrm{p}<0.001)$ achieved at $250 \mathrm{mg} / \mathrm{ml}$ concentration [13].

Safety data: There is a rather contradicting data on the safety of the hydro alcoholic leaf extract of $C$. aurea. An acute toxicity study on the $80 \%$ methanolic leaf extract conducted by Birhanu et al. [82] at a limit dose of $2000 \mathrm{mg} / \mathrm{kg}$ showed that the plant failed to display any signs of mortality and morbidity for up to 14 days [82]. In contrast, a previous study uncovered that the limit test dose of $2000 \mathrm{mg} / \mathrm{kg}$ orally administered sequentially to female mice caused mortality in all test animals. Consequently, the dose was tapered to $300 \mathrm{mg} / \mathrm{kg}$ at which the extract didn't show any visible signs of acute toxicity as well as mortality [76].

\section{Methodology}

Various types of documents such as books, published research articles and theses were thoroughly explored to collect valuable information regarding the medicinal plants used for the treatment of 
Citation: Meresa A, Fekadu N, Degu S, Tadele A, Geleta B (2017) An Ethno Botanical Review on Medicinal Plants Used for the Management of Hypertension. Clin Exp Pharmacol 7: 228. doi:10.4172/2161-1459.1000228

Page 8 of 16

hypertension. The references of identified articles and hand searched journals on ethno botany, herbal medicine such as the journal of ethno pharmacology were also searched. Various web sites including Google scholar and pub med have also been searched for the collection of data using important related key words such as Ethno botanical survey,
Ethiopian herbal medicine, antihypertensive plants, etc. Using the sources and tools, the scientific, family and local names of each plant species together with the parts used, method of preparation as well as other medicinal benefits of the identified plants were clearly described and presented in a Table 1.

\begin{tabular}{|c|c|c|c|c|c|c|}
\hline S No. & $\begin{array}{l}\text { Scientific } \\
\text { Name }\end{array}$ & Local Name & Part(s) Used & $\begin{array}{l}\text { Method of } \\
\text { Preparation }\end{array}$ & Medicinal Use(s) & References \\
\hline 1 & $\begin{array}{l}\text { Premna schimperi } \\
{[\text { Lamiaceae }]\{\text { Engl }\}} \\
\text { [lamiaceae }]\end{array}$ & $\begin{array}{l}\text { Chocho }(\mathrm{Am}) \\
\text { Uregessa }(\mathrm{SH})\end{array}$ & Leaf & Not Specified & $\begin{array}{l}\text { Hypertension, hemorrhoids, wound, } \\
\text { inflammation of skin }\end{array}$ & [83] \\
\hline 2 & $\begin{array}{l}\text { Cymbopogon citrates } \\
\text { [Poaceae] }\end{array}$ & Tej-sar (Am) & Whole part & Not Specified & $\begin{array}{l}\text { Hypertension, abortifacient, } \\
\text { bronchitis, cold, fever, malaria, } \\
\text { hemorrhoids, tooth ache }\end{array}$ & [84-87] \\
\hline 3 & Thalictrum rhyme & Sirebizu (Am) & Root & $\begin{array}{l}\text { The root is ground, } \\
\text { blended with honey } \\
\text { and taken for seven- } \\
\text { days orally. }\end{array}$ & $\begin{array}{l}\text { Flu, hypertension, abdominal } \\
\text { wounds or Stomach ache, unknown } \\
\text { diseases }\end{array}$ & {$[86]$} \\
\hline 4 & $\begin{array}{l}\text { Aloe spp. } \\
\text { [Asphodelaceae] }\end{array}$ & Eret (Am) & Gel latex & Not Specified & $\begin{array}{l}\text { Rheumatic pain, hemorrhoid, } \\
\text { hypertension, Emollient, purgative, } \\
\text { anti-helminthes, anti-fungal, } \\
\text { antiseptic and cosmetic, for fever, } \\
\text { spleen and liver troubles, anti- } \\
\text { diabetic etc.. }\end{array}$ & [86-89]. \\
\hline 5 & $\begin{array}{l}\text { Allium cepa } \quad \mathrm{L} . \\
\text { [Amaryllidaceae] }\end{array}$ & $\begin{array}{l}\text { Key shinkurt } \\
(\mathrm{Am})\end{array}$ & $\begin{array}{l}\text { Bulb (fresh) seed/ } \\
\text { Root and leaf }\end{array}$ & $\begin{array}{l}\text { The seed is } \\
\text { crushed, immersed } \\
\text { in little water for } 1 \\
\text { day, then filtered } \\
\text { using a clean cloth } \\
\text { and is drunk before } \\
\text { food. }\end{array}$ & $\begin{array}{l}\text { Asthma, Malaria, Blotting } \\
\text { hypertension }\end{array}$ & [90-92]. \\
\hline 6 & Botanically unidentified & Bekurelomi(Am & Fruit and leaf & $\begin{array}{l}\text { The juice is drunk } \\
\text { most frequently. }\end{array}$ & $\begin{array}{l}\text { Cholesterol, liver, bile pancreas } \\
\text { problems, cancer, Hypertension, } \\
\text { obesity }\end{array}$ & {$[86]$} \\
\hline 7 & $\begin{array}{l}\text { Carica papaya L. } \\
\text { [Caricaceae] }\end{array}$ & $\begin{array}{l}\text { Papaya } \\
\text { (Am) }\end{array}$ & Seeds & $\begin{array}{l}\text { The seed is ground, } \\
\text { blended with honey } \\
\text { and taken with } \\
\text { empty stomach. }\end{array}$ & $\begin{array}{l}\text { Gastric, constipation, malaria } \\
\text { hypertension, Amoebic diseases, } \\
\text { abdominal colic }\end{array}$ & {$[86]$} \\
\hline 8 & $\begin{array}{l}\text { Allium sativa L. } \\
\text { [Alliliaceae] }\end{array}$ & $\begin{array}{l}\text { Nech shinkurt } \\
(\mathrm{Am})\end{array}$ & Bulb & $\begin{array}{l}\text { The bulb is } \\
\text { frequently eaten } \\
\text { with food }\end{array}$ & $\begin{array}{l}\text { Hypertension, snake bit, abdominal } \\
\text { pain, antibacterial, insecticidal, } \\
\text { cholesterol diarrheal, diabetes, } \\
\text { cancer, anti-microbial, antifungal, } \\
\text { anti-asthma, anti-malarial }\end{array}$ & [86-97] \\
\hline 9 & $\begin{array}{l}\text { Ajugainte grifolia } \\
\text { [Lamiaceae] }\end{array}$ & $\begin{array}{l}\text { Armagusa }(\mathrm{Am}) \\
\text { Harmagusa[O] }\end{array}$ & Leaf & $\begin{array}{l}\text { The leaf is boiled } \\
\text { with butter, filtered } \\
\text { and taken orally }\end{array}$ & $\begin{array}{l}\text { Stomach diseases, hypertension, } \\
\text { Cholesterol, asthma, bad spirit, } \\
\text { addiction problems, diabetes }\end{array}$ & [86-99] \\
\hline 10 & $\begin{array}{l}\text { Merendra bengalensis } \\
\text { (Roxb.) Benth. [Lamiaceae] }\end{array}$ & $\begin{array}{l}\text { Mesaguh } \\
(\mathrm{T})\end{array}$ & Leaf & $\begin{array}{l}\text { The leaf is crushed, } \\
\text { filtered and the } \\
\text { filtrate is taken orally }\end{array}$ & Ascariasis, hypertension & [100] \\
\hline 11 & $\begin{array}{l}\text { Berasama abtyssinica } \\
\text { Fresen [Melianthaceae] }\end{array}$ & $\begin{array}{l}\text { Azamir } \\
(\text { Am) } \\
\text { dobi } \\
\text { warabechaa } \\
(\mathrm{O})\end{array}$ & Leaf (fresh) and root & $\begin{array}{l}\text { The leaf is boiled } \\
\text { with water and the } \\
\text { filtrate is mixed with } \\
\text { teff powder and } \\
\text { eaten with yoghurt. } \\
\text { Alternatively, the } \\
\text { root is crushed, } \\
\text { mixed with honey } \\
\text { and eaten. }\end{array}$ & 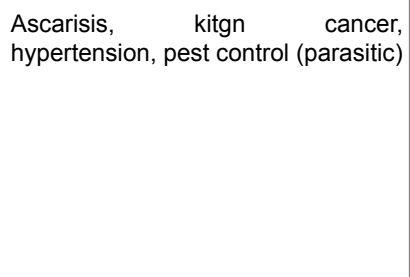 & {$[86,101]$} \\
\hline 12 & $\begin{array}{l}\text { Hibiscus sabdariffa } \\
\text { [Malvaceae] }\end{array}$ & Kedkedie(Am) & Flower & Not Specified & $\begin{array}{l}\text { To increase and decrease blood } \\
\text { pressure depending } \\
\text { concentration. }\end{array}$ & {$[86,102]$} \\
\hline
\end{tabular}


Citation: Meresa A, Fekadu N, Degu S, Tadele A, Geleta B (2017) An Ethno Botanical Review on Medicinal Plants Used for the Management of Hypertension. Clin Exp Pharmacol 7: 228. doi:10.4172/2161-1459.1000228

\begin{tabular}{|c|c|c|c|c|c|c|}
\hline 13 & $\begin{array}{l}\text { Moringa stenopetala } \\
\text { [Moringaceae] }\end{array}$ & $\begin{array}{l}\text { Shiferaw } \\
\text { (Am) } \\
\text { Shifera } \\
\text { (Sd) } \\
\text { Kelanqi } \\
\text { (Ha) }\end{array}$ & Dried leaf & $\begin{array}{l}\text { The dried leaf is } \\
\text { prepared as a tea } \\
\text { and taken orally } \\
\text { orthe fresh leaf is } \\
\text { boiled with Allium } \\
\text { cepa and Capsicum } \\
\text { annuum, oil is } \\
\text { added and taken } \\
\text { orally }\end{array}$ & $\begin{array}{l}\text { Hypertension, diabetes, kidney } \\
\text { infection, malaria, hypoglycemic, } \\
\text { anti-leis menial, ant-fertility, anti- } \\
\text { hyperglycemic anti-cancer, anti- } \\
\text { asthmatic, antioxidant. }\end{array}$ & {$[47-105]$} \\
\hline 14 & $\begin{array}{l}\text { Achyranthes aspera L. } \\
\text { [Amaranthaceae] }\end{array}$ & $\begin{array}{l}\text { Telenji } \\
(\mathrm{Am})\end{array}$ & $\begin{array}{l}\text { Root } \\
\text { and tip shoot }\end{array}$ & $\begin{array}{l}\text { The root is sniffed } \\
\text { through the nostrils }\end{array}$ & $\begin{array}{l}\text { Stabling pain, } \\
\text { leishmaniasis, urine retention, } \\
\text { hypertension, kintarot, wound }\end{array}$ & [86] \\
\hline 15 & Botanically unidentified & $\begin{array}{l}\text { Yedemie } \\
(\mathrm{Am}) \\
\text { Etse-demawit } \\
(\mathrm{G})\end{array}$ & Root and leaf & Not Specified & Hypertension & [86] \\
\hline 16 & $\begin{array}{l}\text { Lupines termis Forssk } \\
\text { [Leguminosae]/Fabaceae] }\end{array}$ & $\begin{array}{l}\text { Gibto } \\
\text { (Am) }\end{array}$ & Seed & $\begin{array}{l}\text { Seeds are soaked } \\
\text { with water for } 5 \\
\text { days, after } \\
\text { discarding the water } \\
\text { the decanted seeds } \\
\text { arethen eaten. }\end{array}$ & $\begin{array}{l}\text { Cleans blood, pneumonia, bowl and } \\
\text { hypertension related problems, } \\
\text { Giardiasis }\end{array}$ & {$[86-107]$} \\
\hline 17 & $\begin{array}{l}\text { Spinacia } \\
\text { oleracea[Amaranthaceae] }\end{array}$ & $\begin{array}{l}\mathrm{Kel} \\
(\mathrm{Am})\end{array}$ & Leaf & Eat frequently. & Hypertension, obesity & {$[10,86]$} \\
\hline 18 & $\begin{array}{l}\text { Hordeum vulgare L. } \\
\text { [Poaceae] }\end{array}$ & Gebs (Am) & Leaf & $\begin{array}{l}\text { Germinated barley } \\
\text { and Sorghum are } \\
\text { baked in bread, } \\
\text { broken up and } \\
\text { fermented together } \\
\text { with malt starter, } \\
\text { brewed and distilled. }\end{array}$ & Hypertension & {$[86,108]$} \\
\hline 19 & $\begin{array}{l}\text { Trigonellafoenumgraecum } \mathrm{L} \text {. } \\
\text { [Fabaceae] }\end{array}$ & Abish (Am) & Seeds & Not Specified & $\begin{array}{l}\begin{array}{l}\text { Cholesterol, } \\
\text { stomachache, }\end{array} \text { antispasmodic, } \\
\text { powder used for wound dressing }\end{array}$ & {$[86,108]$} \\
\hline 20 & $\begin{array}{l}\text { Dovyalisabyssinica (A. rich) } \\
\text { Warb [Flacourtiaceae] }\end{array}$ & $\begin{array}{l}\text { Yehabeshaquo } \\
\text { shm } \\
(\mathrm{Am})\end{array}$ & Root and stem tuber & $\begin{array}{l}\text { Root and stem tuber } \\
\text { are smashed, mixed } \\
\text { and drunk with } \\
\text { alcohol }\end{array}$ & $\begin{array}{l}\text { Ascariasis, hypertension, bleeding } \\
\text { gum, }\end{array}$ & {$[109]$} \\
\hline 21 & $\begin{array}{l}\text { Tamarindusindica } \quad \text { L. } \\
\text { [Fabaceae] }\end{array}$ & $\begin{array}{l}\text { Humer(T) } \\
\operatorname{roka}(A m)\end{array}$ & Fruit & Not Specified & $\begin{array}{l}\text { Abdominal problems, } \\
\text { hypertension, } \\
\text { Spleenomegally }\end{array}$ & [110] \\
\hline 22 & $\begin{array}{l}\text { Ferula communis } \mathrm{L} \text {. } \\
\text { [Apiaceae] }\end{array}$ & Enslal(Am) & Leaf & Not Specified & $\begin{array}{l}\text { Hypertension, } \\
\text { urination problems, } \\
\text { kidney problems }\end{array}$ & [109] \\
\hline 23 & $\begin{array}{l}\text { Rumex abyssinicus } \\
\text { [Polygonaceae } \\
\text { ] }\end{array}$ & $\begin{array}{l}\text { Mekemeko } \\
(\mathrm{Am})\end{array}$ & Root & $\begin{array}{l}\text { The root is crushed } \\
\text { into powder, mixed } \\
\text { with bulbs of garlic. } \\
\text { The mixture is } \\
\text { boiledwith water and } \\
\text { taken with milk }\end{array}$ & $\begin{array}{l}\text { Hypertension, asthma, liver } \\
\text { problems, wound, common cold, } \\
\text { cancer, colorectal, stomach ache, } \\
\text { inflammation and painful conditions }\end{array}$ & [107-116] \\
\hline 24 & $\begin{array}{l}\text { Thymes serrulatus } \\
\text { [Lamiaceae] }\end{array}$ & Tosghn(Am) & Leaf and flower & $\begin{array}{l}\text { Fresh leaves are } \\
\text { soaked with hot } \\
\text { water andthe filtrate } \\
\text { taken orally. }\end{array}$ & $\begin{array}{l}\text { Blood pressure, general pain } \\
\text { syndrome, influenza, abdominal } \\
\text { pain, ascariasis, intestinal parasites, } \\
\text { renal disease }\end{array}$ & {$[32-118]$} \\
\hline 25 & $\begin{array}{l}\text { Thymus schimperi } \\
\text { [Lamiaceae ] }\end{array}$ & Tosghn(Am) & $\begin{array}{l}\text { Leaf, flower and } \\
\text { root }\end{array}$ & $\begin{array}{l}\text { The leaves are } \\
\text { dried, powdered, } \\
\text { and mixed with the }\end{array}$ & $\begin{array}{l}\text { Blood pressure, general pain } \\
\text { syndrome, influenza, abdominal } \\
\text { pain, intestinal parasites, gastritis, }\end{array}$ & [63-120] \\
\hline
\end{tabular}


Citation: Meresa A, Fekadu N, Degu S, Tadele A, Geleta B (2017) An Ethno Botanical Review on Medicinal Plants Used for the Management of Hypertension. Clin Exp Pharmacol 7: 228. doi:10.4172/2161-1459.1000228

\begin{tabular}{|c|c|c|c|c|c|c|}
\hline & & & & $\begin{array}{l}\text { seed powder and } \\
\text { eaten. } \\
\text { The root is dried, } \\
\text { powdered, and drink } \\
\text { consumed with tea }\end{array}$ & $\begin{array}{l}\text { cough, anti-oxidant, antifungal and } \\
\text { antimicrobial activities }\end{array}$ & \\
\hline 26 & $\begin{array}{l}\text { Syzygium guineense } \\
\text { [Myrtaceae ] }\end{array}$ & Dokma(Am) & Leaf & Not Specified & $\begin{array}{l}\text { Malaria, skin rash, itching, diarrheal, } \\
\text { gastro-intestinal } \\
\text { hypertension, ansets, } \\
\begin{array}{l}\text { analgesic and inflammatory, } \\
\text { activities }\end{array}\end{array}$ & [32] \\
\hline 27 & $\begin{array}{l}\text { Balanites aegyptiaca }(\mathrm{L})[\mathrm{Del} \\
\text { Balanitaceae] }\end{array}$ & $\begin{array}{l}\text { Dhumuko } \\
(\mathrm{Hm})\end{array}$ & Bark & $\begin{array}{l}\text { Inside of the bark is } \\
\text { peeled off, infusion } \\
\text { is made with water, } \\
\text { filtered and drunk }\end{array}$ & Hypertension & [103] \\
\hline 28 & $\begin{array}{l}\text { Cadaba farinosa Forssk } \\
\text { Capparidaceae }\end{array}$ & $\begin{array}{l}\text { Dhela } \\
(\mathrm{Hm})\end{array}$ & Root & $\begin{array}{l}\text { Roots are chopped, } \\
\text { boiled with meat } \\
\text { soup and drunk }\end{array}$ & Hypertension, malaria & {$[103]$} \\
\hline 29 & $\begin{array}{l}\text { Euphorbia sp. } \\
\text { Euphorbaceae }\end{array}$ & $\begin{array}{l}\text { Kera } \\
(\mathrm{Hm})\end{array}$ & Bark & $\begin{array}{l}\text { Fresh bark is } \\
\text { chopped, infusion is } \\
\text { made, mixed with } \\
\text { honey and drunk }\end{array}$ & Hypertension & [103] \\
\hline 30 & $\begin{array}{ll}\begin{array}{l}\text { Leucaena } \\
\text { (Lam) De Wit }\end{array} & \text { leucocephala } \\
\text { Fabaceae } & \end{array}$ & $\begin{array}{l}\text { Lalomb } \\
\text { Aka } \\
(\mathrm{Hm})\end{array}$ & Stem & $\begin{array}{l}\text { Different parts of the } \\
\text { plants are mixed, } \\
\text { crushed, macerated/ } \\
\text { infused in water, } \\
\text { filtered, mix with } \\
\text { honey and milk and } \\
\text { then drunk }\end{array}$ & $\begin{array}{l}\text { Hypertension, intestinal parasites, } \\
\text { irregular menstruation, loss of } \\
\text { appetite }\end{array}$ & {$[103]$} \\
\hline 31 & $\begin{array}{l}\text { Meliaazedarch L. } \\
\text { [Meliaceae] }\end{array}$ & $\begin{array}{l}\text { Mimi-zaf(Am) } \\
\text { or Fayo (O) }\end{array}$ & Leaf & $\begin{array}{l}\text { Leaves are pounded } \\
\text { and the juice is } \\
\text { taken orally }\end{array}$ & $\begin{array}{l}\text { Hypertension, prevent irregularity of } \\
\text { menstrual cycle } \\
\text { diarrhea of human }\end{array}$ & [121] \\
\hline 32 & $\begin{array}{l}\text { Catha edulis (Vahl) Endl. } \\
\text { [Celastraceae] }\end{array}$ & Chat (Am) & Fresh leaf & $\begin{array}{l}\text { Fresh leaves are } \\
\text { chewed }\end{array}$ & Hypertension, asthma & [122] \\
\hline 33 & $\begin{array}{l}\text { Citrus aurantiifolia (Christm.) } \\
\text { [Swingle][Rutaceae] }\end{array}$ & $\begin{array}{l}\text { Tutto } \\
\text { Lemon } \\
(\mathrm{Am})\end{array}$ & Fruit & $\begin{array}{l}\text { The whole fruit and } \\
\text { fruit juice are taken }\end{array}$ & $\begin{array}{l}\text { Hypertension, Skin cutting, Cough, } \\
\text { stomachache, } \\
\text { body odor, tetanus, wound, } \\
\text { constipation }\end{array}$ & [104-122] \\
\hline 34 & $\begin{array}{l}\text { Rumex nepalensis Spreng. } \\
\text { Polygonaceae }\end{array}$ & Tullet (Am) & Fresh leaf & $\begin{array}{l}\text { Fresh leaves are } \\
\text { boiled and drunk. }\end{array}$ & $\begin{array}{l}\text { Quaquchia, Hypertension, Amoebic } \\
\text { dysentery and Hemorrhoid }\end{array}$ & [122] \\
\hline 35 & $\begin{array}{l}\text { Citrus aurantium } \\
\text { [Rutaceae] }\end{array}$ & $\begin{array}{l}\text { Komtatie } \\
\text { (Am) } \\
\text { Qomxaaxxee } \\
\text { (O) }\end{array}$ & $\begin{array}{l}\text { Flower } \\
\text { fruit }\end{array}$ & $\begin{array}{l}\text { The juice is drunk } \\
\text { once a day. }\end{array}$ & Hypertension & {$[114,123]$} \\
\hline 36 & $\begin{array}{l}\text { Citrus limon (L.) Burm. F } \\
\text { [Rutaceae] }\end{array}$ & Lomi (Am) & Fresh juice & $\begin{array}{l}\text { Fresh juice is mixed } \\
\text { with tomato and } \\
\text { given orally }\end{array}$ & Amoebiasis, Hypertension & {$[124,125]$} \\
\hline 37 & $\begin{array}{l}\text { Calpurnea aurea (Alt.) Benth } \\
\text { [Fabaceae] }\end{array}$ & $\begin{array}{l}\text { Digita }(\mathrm{Am}) \\
\text { Cekkatta(Sd) } \\
\text { Cheka }(\mathrm{O})\end{array}$ & Seeds & $\begin{array}{l}\text { The seeds are } \\
\text { crushed and sniffed } \\
\text { through the nostrils }\end{array}$ & $\begin{array}{l}\text { Hypertension, jaundice impotence } \\
\text { diarrhea, rabies, amoebiasis and } \\
\text { giardiasis, diabetes, woundhealing, } \\
\text { trachoma, malaria, syphilis, fungal } \\
\text { diseases }\end{array}$ & {$[13,126]$} \\
\hline 38 & $\begin{array}{l}\text { Crinum abyssinicum (Hochst) } \\
\text { ex A. Rich [Amaryllidaceae] }\end{array}$ & $\begin{array}{l}\text { Yejib shinkurt } \\
(\text { Am) }\end{array}$ & $\begin{array}{l}\text { Shoot tip } \\
\text { (fresh) }\end{array}$ & $\begin{array}{l}\text { The liquid from the } \\
\text { shoot tip is } \\
\text { squeezed, mixed } \\
\text { with water, and } \\
\text { drunk }\end{array}$ & Hypertension, diabetes & [104] \\
\hline
\end{tabular}


Citation: Meresa A, Fekadu N, Degu S, Tadele A, Geleta B (2017) An Ethno Botanical Review on Medicinal Plants Used for the Management of Hypertension. Clin Exp Pharmacol 7: 228. doi:10.4172/2161-1459.1000228

Page 11 of 16

\begin{tabular}{|c|c|c|c|c|c|c|}
\hline 39 & $\begin{array}{l}\text { Foeniculum vulgare Miller. } \\
\text { [Lauraceae] }\end{array}$ & $\begin{array}{l}\text { Wallaago } \\
\text { Ensilal(Am) }\end{array}$ & Fresh leaves & $\begin{array}{l}\text { Squeezed and } \\
\text { drank } 1 \text { glass cup/ } \\
\text { Boiled and drank }\end{array}$ & $\begin{array}{l}\text { Hypertension, diabetes, gonorrhea, } \\
\text { Kidney } \\
\text { Problem, stomachache }\end{array}$ & {$[68,104]$} \\
\hline 40 & $\begin{array}{l}\text { Persea americana Mill) } \\
\text { [lauraceae] }\end{array}$ & $\begin{array}{l}\text { Avocado(Am) } \\
\text { Abukato } \\
(\mathrm{Sd})\end{array}$ & Dried fruit & $\begin{array}{l}\text { Crushed, } \\
\text { powdered, mixed } \\
\text { with coffee and } \\
\text { drank }\end{array}$ & Hypertension, diarrhea & {$[104,127]$} \\
\hline 41 & $\begin{array}{ll}\text { Ajuga } & \text { intergrifolia } \\
\text { [Lamiaceae] } & \end{array}$ & $\begin{array}{l}\text { Armagusa } \\
\text { (O) }\end{array}$ & Leaf & Not Specified & $\begin{array}{l}\text { Anti-hypotensive, elephantiasis, } \\
\text { Breastmassage }\end{array}$ & [128] \\
\hline 42 & Rosa abtyssinica [Rosaceae] & $\begin{array}{l}\text { Kega } \\
(\mathrm{Am})\end{array}$ & Fruit & $\begin{array}{l}\text { Powdered fruits are, } \\
\text { mixed with water } \\
\text { and drunk }\end{array}$ & Hypertension & [129] \\
\hline 43 & $\begin{array}{l}\text { Menthax } \\
\text { piperata L. } \\
\text { [Lamiaceae] }\end{array}$ & Nana (O) & Leaf & $\begin{array}{l}\text { The juice of } \\
\text { squeezed } \\
\text { leaf is drunk }\end{array}$ & Common colds, hypertension & [87-130] \\
\hline 44 & $\begin{array}{l}\text { Ocimum } \\
\text { [Labiatae] }\end{array}$ & Damakase (Am) & Leaf & $\begin{array}{l}\text { Fresh leaves are } \\
\text { pounded and juice } \\
\text { is prepared. Then, } \\
\text { taken orally, three } \\
\text { times a day for three } \\
\text { days. }\end{array}$ & Hypertension & [130] \\
\hline 45 & $\begin{array}{l}\text { Hagenia abyssinica (Bruce) } \\
\text { J. F. Gmel., [Rosaceae] }\end{array}$ & Kosso (Am) & $\begin{array}{l}\text { Fresh flower and } \\
\text { fruit }\end{array}$ & $\begin{array}{l}\text { Fresh flower and } \\
\text { fruit are boiled with } \\
\text { little water and } \\
\text { mixed with alcohol } \\
\text { given orally }\end{array}$ & $\begin{array}{l}\text { Tape worm, } \\
\text { hypertension }\end{array}$ & [79-131] \\
\hline 46 & $\begin{array}{l}\text { Dioscorea praehensilis } \\
\text { Benth [Dioscoreaceae] }\end{array}$ & $\begin{array}{l}\text { Wacino } \\
\text { (O) }\end{array}$ & Bulb & $\begin{array}{l}\text { Bulbs are boiled and } \\
\text { eaten }\end{array}$ & $\begin{array}{l}\text { Tonsillitis, } \\
\text { hyper tension }\end{array}$ & [68] \\
\hline 47 & $\begin{array}{l}\text { Leucas } \quad \text { martinicensis } \\
\text { (Jacq.)R.B. } \\
\text { [Lamiaceae] }\end{array}$ & $\begin{array}{l}\text { Raas } \\
\text { Kimir } \\
(\mathrm{Am})\end{array}$ & Leaf & $\begin{array}{l}\text { Crushed leaves are, } \\
\text { squeezed and half a } \\
\text { coffeecup of the } \\
\text { liquid is drunk }\end{array}$ & hypertension, malaria & [68] \\
\hline 48 & $\begin{array}{l}\text { Salvia tiliifolia Vahl, } \\
\text { [Lamiaceae] }\end{array}$ & Aqorarach (Am) & Fresh leaf & $\begin{array}{l}\text { Fresh leaf juice is } \\
\text { mixed with little } \\
\text { water and given } \\
\text { orally }\end{array}$ & $\begin{array}{l}\text { Hypertension, tonsillitis, febrile } \\
\text { illness }\end{array}$ & [125] \\
\hline 49 & $\begin{array}{l}\text { Psidium guava } \\
\text { [myrtaceae] }\end{array}$ & $\begin{array}{l}\text { Zeytun } \\
\text { (Am) }\end{array}$ & Leaf & Not Specified & Hypertension & [132] \\
\hline 50 & $\begin{array}{l}\text { Datura stramonium L. } \\
\text { [Solonaceae] }\end{array}$ & Asangra $(\mathrm{O})$ & Root & $\begin{array}{l}\text { The root is decocted } \\
\text { overnight and mixed } \\
\text { with rancid butter }\end{array}$ & $\begin{array}{l}\text { Asthma, hypertension, diabetes } \\
\text { mellitus, toothache }\end{array}$ & [99] \\
\hline 51 & $\begin{array}{l}\text { Centarium pulchellum } \\
\text { [Gentianaceae] }\end{array}$ & $\begin{array}{l}\text { Lesser } \\
\text { (En) }\end{array}$ & Root & $\begin{array}{l}\text { The root is boiled in } \\
\text { water and taken } \\
\text { orally }\end{array}$ & $\begin{array}{l}\text { Gastric, abdominal pain, } \\
\text { hypertension, diabetes, elimination } \\
\text { of stones from kidney and urethra }\end{array}$ & [133] \\
\hline 52 & $\begin{array}{l}\text { Dorstenia barnimiana } \\
\text { Schwienf) } \\
\text { [Moraceae] }\end{array}$ & $\begin{array}{l}\text { Work bemeda } \\
(\mathrm{Am})\end{array}$ & Root & Not Specified & $\begin{array}{l}\text { Blood pressure, Hepatitis donkey's } \\
\text { wart, cancer, rabies, syphilis, weight } \\
\text { loss, diarrhea and fever }\end{array}$ & {$[86,134]$} \\
\hline 53 & $\begin{array}{l}\text { Impomea sp. } \\
\text { [Convolvulaceae] }\end{array}$ & $\begin{array}{l}\text { Fiatsut } \\
\text { (Am) }\end{array}$ & Leaf & Not Specified & $\begin{array}{l}\text { Babies' sickness, hypertension, } \\
\text { cancer }\end{array}$ & [86] \\
\hline 54 & $\begin{array}{l}\text { Vernonia amygdalina } \\
\text { [Asteraceae] }\end{array}$ & $\begin{array}{l}\text { Grawa } \\
\text { (Am) }\end{array}$ & Leaf & Not Specified & $\begin{array}{l}\text { stimulates the digestive system and } \\
\text { helps in reduction of fever, to treat }\end{array}$ & [135] \\
\hline
\end{tabular}




\begin{tabular}{|c|c|c|c|c|c|c|}
\hline & & & & & $\begin{array}{l}\text { hiccups and kidney disease, as a } \\
\text { remedy against high blood pressure }\end{array}$ & \\
\hline 55 & $\begin{array}{l}\text { Asparagus } \\
\text { aethiopicus[Asparagaceae] }\end{array}$ & Yeset-kest (Am) & Root & Not Specified & Taenicidal, hypertension & [131] \\
\hline 56 & $\begin{array}{l}\text { Artemisisa absinthium L. } \\
\text { [Asteraceae] }\end{array}$ & $\begin{array}{l}\text { Aguffa/ natra } \\
\text { (O) }\end{array}$ & Leaf & Not Specified & $\begin{array}{l}\text { hypertension, cough, febrile, } \\
\text { malaria, } \\
\text { dandruff }\end{array}$ & {$[92]$} \\
\hline 57 & $\begin{array}{l}\text { Acanthospermum } \\
\text { hispidum[Asteraceae] }\end{array}$ & $\begin{array}{l}\text { Harmaagussa( } \\
\text { O) }\end{array}$ & Leaf & $\begin{array}{l}\text { Leaves are crushed, } \\
\text { boiled and one tea } \\
\text { cup is drunk within } \\
12 \mathrm{~h} \text { interval for a } \\
\text { week. }\end{array}$ & Hypertension & [136] \\
\hline 58 & $\begin{array}{l}\text { Croton macrostachys } \\
\text { Hochest. ex. A. Rich } \\
\text { [Euphorbiaceae] }\end{array}$ & Bisana (Am) & Root & Not Specified & $\begin{array}{l}\text { Treats cancer, diabetes, } \\
\text { hypertension, dysentery, fever, } \\
\text { hypercholesterolemiar malaria, } \\
\text { inflammation, ulcer, pain, infectious } \\
\text { diseases }\end{array}$ & {$[88]$} \\
\hline 59 & $\begin{array}{l}\text { Salvadoroa persica L. } \\
\text { [Salvadoraceae] }\end{array}$ & Kerja (Ha) & Root/stem & $\begin{array}{l}\text { Root or stem is } \\
\text { chewed and juice is } \\
\text { kept in mouse }\end{array}$ & $\begin{array}{l}\text { Abdominal colic, malaria, blood } \\
\text { pressure, gum bleeding }\end{array}$ & [103] \\
\hline 60 & $\begin{array}{l}\text { Stevia rebaudiana Bertoni } \\
\text { [Asteraceae ] }\end{array}$ & Not specified & Leaf & Not Specified & $\begin{array}{l}\text { Antihypertensive, antimicrobial, anti- } \\
\text { obesity and antioxidant activities }\end{array}$ & {$[88]$} \\
\hline 61 & $\begin{array}{l}\text { Meriandra dianthera } \\
\text { [Lamiaceae] }\end{array}$ & $\begin{array}{l}\text { Mesaguh } \\
(\mathrm{T})\end{array}$ & Leaf & Not Specified & Hypertension and diarrhea & [137] \\
\hline 62 & $\begin{array}{l}\text { Otostegia integrifolia Benth } \\
\text { [Lamiaceae] }\end{array}$ & Chendog $(T)$ & Leaf & $\begin{array}{l}\text { Leaves are boiled in } \\
\text { water and a cup of } \\
\text { solution is taken } \\
\text { every morning until } \\
\text { recovery }\end{array}$ & Hypertension & [137] \\
\hline 63 & $\begin{array}{l}\text { Zingiber officinale Rosc. } \\
\text { [Zingiberaceae] }\end{array}$ & Gengible $(T)$ & Rhizome & $\begin{array}{l}\text { The rhizome is } \\
\text { chewed }\end{array}$ & Hypertension & [137] \\
\hline 64 & $\begin{array}{l}\text { Schinus molle L } \\
\text { [Anacardiaceae] }\end{array}$ & $\begin{array}{l}\text { Tselim berbere } \\
\text { (T) }\end{array}$ & Stem & The stem is chewed & Hypertension & [137] \\
\hline 65 & $\begin{array}{l}\text { Crepis rueppellii Sch. Bip } \\
\text { [Asteraceae] }\end{array}$ & $\begin{array}{l}\text { Yemidir gusmt } \\
{[\mathrm{Am}]}\end{array}$ & Root & $\begin{array}{l}\text { Root is boiled in } \\
\text { water and taken as } \\
\text { tea at bed time }\end{array}$ & Hypertension, dysentery with blood & [138] \\
\hline 66 & $\begin{array}{l}\text { Satureja punctata Benth. Briq } \\
\text { [Lamiaceae] }\end{array}$ & Lomishet (Am) & Leaf & $\begin{array}{l}\text { Leaves are cooked } \\
\text { and the extract is } \\
\text { taken orally }\end{array}$ & $\begin{array}{l}\text { Treatment of liver diseases, } \\
\text { hypertension, diabetes and other } \\
\text { disorders }\end{array}$ & [139] \\
\hline
\end{tabular}

Table 1: List of medicinal plants used for management of hypertension.

Am: Amharigna, O: Afaan Oromoo, T: Tigrigna, Sd: Sidamigna, G: Geez, S: Somaligna, Ha: Hammerigna.

\section{Conclusion}

The prevalence of hypertension and the use of herbal medicines have been shown to increase all over the world, particularly across the developing countries. More than $80 \%$ of people who live in the developing countries rely on herbal medicines for their health care needs. The medicinal plants reported in this study are antihypertensive herbal agents that have been studied scientifically as well as used in Ethiopian traditional medicine. In the present review, a total of sixty six medicinal plants have been identified and recorded for their use in management of hypertension. Though most of these medicinal plants are widely utilized in different parts of the country, only safety and efficacy information of some of them such as Moringa stenopetala, Thymus serrulatus, Thymus schimperi, Syzygium guineense and
Calupurinea aurea were scientifically tested in animals. Thus, it is relevant for recent and future researchers in the field to conduct the safety and efficacy study of the remaining traditional claimed medicinal plants and generate the information to protect the public health.

\section{Acknowledgements}

We would like thank you all researchers and contributors for generating these research data's compiled as a review document.

\section{References}

1. Tra Bi HF, Irie GM, Kohue CCN, Clejesson HBM (2008) Therapeutic studies of some plants used in the treatment of hypertension and diabetes: two emerging diseases in Côte d'Ivoire. Science and Nature 5: $39-48$. 
2. Amel B (2013) Traditional treatment of high blood pressure and diabetes in Souk Ahras District. J Pharmacogn Phytother 5: 12-20.

3. Reddy KS, Katan MB (2004) Diet, nutrition and the prevention of hypertension and cardiovascular diseases. Public Health Nutrition 7: $167-186$.

4. (2013) Status Report on Hypertension in Africa; Conference of Ministers of Health (CAMH6). 6th Ordinary Session, CAMH/Exp/6, Addis Ababa, Ethiopia.

5. Tesfaye F (2008) Epidemiology of cardiovascular disease risk factors in Ethiopia: the rural-urban gradient. Doctoral Dissertation Published by Umeå University, Epidemiology and Public Health Sciences.

6. World Health Organization (2013) A Global Brief on Hypertension: World Health Day.

7. Geleta B, MakonnenE, Debella A, Tadele A (2016) In vivo Antihypertensive and Antihyperlipidemic Effects of the Crude Extracts and Fractions of Moringa stenopetala (Baker f.) Cufod. Leaves in Rats. Frontiers in pharmacology b; 7: 97.

8. Kloet A, KrauseE, Shi P, Zubcevic J, Raizada M, et al. (2013) Neuroimmune communication in hypertension and obesity: A new therapeutic angle. Pharmacol Therapeut 138: 428-440.

9. Lakshmi T, Anitha R, Durgha K, Manjusha V (2011) Coping With Hypertension Using Safer Herbal Medicine-A Therapeutic Review. Int J Drug Dev Res 3: 3.

10. Mengistu M. (2007) Hypotensive effects of aqueous extract of Moringa stenopetala in both in vivo and in vitro animal models (Master's Thesis, Addis Ababa University, 2007).

11. Alamgeer A, Akhtar MS, Jabeen Q, Akram M, Khan HU, et al. (2013) Antihypertensive activity of aqueous-methanol extracts of Berberis orthobotrys Bien Ex Aitch in rats. Tropical Journal of Pharmaceutical Research 12: 393-399.

12. Gudina EK, Michael Y, Assegid S (2013) Prevalence of hypertension and its risk factors in southwest Ethiopia: a hospital-based cross-sectional survey. Integrated Blood Pressure Control 6: 111-117.

13. Getiye Y, Tolessa T, Engidawork E (2016) Antihypertensive activity of $80 \%$ methanol seed extract of Calpurnia aurea (Ait.) Benth. subsp. aurea (Fabaceae) is mediated through calcium antagonism induced vasodilation. J Ethnopharmacol 189: 99-106.

14. Rout SK, Dutta S, Sengupta M, Das S, Rout B (2010) Antihypertensive Therapy: The Concepts of Management with Herbal and Synthetic Agents for Pulmonary Hypertension. Int J Pharmaceut Sci Rev Res 3.

15. Talha J, Priyanka M, Akanksha A (2011) Hypertension and herbal plants. Int Res J Pharm 2: 26-30.

16. Kibret KT, Mesfin YM (2015) Prevalence of hypertension in Ethiopia: A systematic meta-analysis. Public Health Reviews 36: 1.

17. Mendis S, Puska P, Norrving B (2011) Global atlas on cardiovascular disease prevention and control: Policies, Strategies and Intervention. Published by the World Health Organization in collaboration with the World Heart Federation and the World Stroke Organization.

18. Kumar J (2013) Epidemiology of Hypertension. Clinical queries: Nephrology 2: 6-61.

19. Nsuadi-Manga F (2014) Medicinal Plants in the Treatment of Hypertension. J Pharmacol Toxicol Res 1: 1-2.

20. Abdissa SG, Feleke Y, Awol M (2015) Prevalence of hypertension and prehypertension in Addis Ababa, Ethiopia: A survey done in recognition of World Hypertension Day, 2014. The Ethiopian Journal of Health Development 29.

21. Etuk EU (2006) A review of medicinal plants with hypotensive or antihypertensive effects. Journal of Medical Science 6: 894-900.

22. EPHA (2012) Emerging Public Health Problems in Ethiopia, Chronic Non-Communicable Diseases. Ethiopian Public Health Association pp: 64-67.

23. Tesfaye F, Byass P, Wall S (2009) Population based prevalence of high blood pressure among adults in Addis Ababa: uncovering a silent epidemic. BMC Cardiovas Disord 9: 1.
24. Abebe SM, Berhane Y, Worku A, Getachew A (2015) Prevalence and associated factors of hypertension: a cross sectional community based study in Northwest Ethiopia. Plos One 10: p.e 0125210.

25. Zein Z, Assefa M (1986) Blood pressure levels and hypertension in rural Ethiopian communities. Ethiop Med J 24: 169-178.

26. Tesfaye F, Nawi N, MinhV, Byass P, Berhane Y, et al. (2007) Association between body mass index and blood pressure across three populations in Africa and Asia. J Human Hypertens 21: 28-37.

27. Nshisso LD, Reese A, Gelaye B, Lemmab S, Berhane Y, et al. (2012) Williams M. Prevalence of hypertension and diabetes among Ethiopian adults. Diabetes and Metabolism Syndrome 6: 36-41.

28. Awoke A, Awoke T, Alemu S, Megabiaw B (2012) Prevalence and associated factors of hypertension among adults in Gondar, Northwest Ethiopia: a community based cross-sectional study. BMC Cardiovas Disord 12: 1.

29. WHO (2004) Ethiopian Strategy Paper. In: World Health Organization: Health Action in Crises.

30. WHO (2009) WHO country cooperation strategy Ethiopia. Publication and language services unit, WHO regional office for Africa, Brazzaville, Republic of Congo.

31. Kalia AN (2005) Text Book of Industrial Pharmacognosy. New Delhi India, Oscar Publication 3.

32. Ayele Y, Urga K, Engidawork E (2010) Evaluation of in vivo antihypertensive and in vitro vasodepressor activities of the leaf extract of Syzygium guineense (Willd) DC. Phytotherapy Research 24: 1457-1462.

33. Tabassum N, Ahmad F (2011) Role of natural herbs in the treatment of hypertension. Pharmacogn Rev 5: 30.

34. Joshi UH, Ganatra TH, Bhalodiya PN, Desai TR, Tirgar PR (2012) Comparative Review on Harmless Herbs with Allopathic Remedies as Anti-Hypertensive. Res J Pharmaceut Biol Chem Sci 3: 673.

35. Ghorbani M (2014) Iranian traditional medicine for treatment of type II diabetes, anxiety and hypertension with introduction of zebrafish model system for their screening. Int J Herbal Med 2: 13-19.

36. Singh P, Mishra A, Singh P, Goswami S, Singh A, et al. (2015) Hypertension and herbal plant for its treatment: a review. Indian Journal of Research in Pharmacy and Biotechnology 3: 358.

37. Munir S, Karim A (2013) South Asian herbal plants as anti-hypertensive agents-A review. Sci Int 1: 2-12.

38. Laelago T, Yohannes T, Lemango F (2016) Prevalence of herbal medicine use and associated factors among pregnant women attending antenatal care at public health facilities in Hossana Town, Southern Ethiopia: facility based cross sectional study. Archives of Public Health 74: 7.

39. Ernst E (2005) The efficacy of herbal medicine-an overview. Fundamental and Clinical Pharmacology 19: 405-409.

40. Mengistu M, Abebe $\mathrm{Y}$, Mekonnen $\mathrm{Y}$, Tolessa $\mathrm{T}$ (2012) In vivo and in vitro hypotensive effect of aqueous extract of Moringa stenopetala. African Health Sci 12: 545-551.

41. World Health Organization (2002) WHO: Traditional Medicine Strategy.

42. World Bank (2001) Ethiopia: traditional medicine and the bridge to better health. Indigenous Knowledge (IK) Notes; no 35. Washington, DC, USA.

43. Kassaye KD, Amberbir A, Getachew B, Mussema Y (2006) A historical overview of traditional medicine practices and policy in Ethiopia. Ethiopian Journal of Health Development 20: 127-134.

44. Agrawal M, Nandini D, Sharma V, Chauhan NS (2010) Herbal remedies for treatment of hypertension. Int J Pharmaceut Sci Res 1: 1-21.

45. Jadhav GB, Saudagar RB, Upasani CD (2013) Animal Models of Hypertension, Diabetes and Diabetic Hypertension: An Overview. World J Pharm Pharmaceut Sci 3: 1150-1164.

46. Humidat AS, Khamaysa IS (2014) The Use of Herbal Medicines by People with Hypertension in Palestine. Diabetes 26: 41-43.

47. Sileshi T, Makonnen E, Debella A, Tesfaye B (2014) Antihyperglycemic and sub chronic toxicity study of Moringa stenopetala leaves in mice. Journal of Coastal Life Medicine 2: 214-221. 
48. Endashaw B (2007) Study on actual situation of medicinal plants in Ethiopia. Prepared for Japan Association for International Collaboration of Agriculture and Forestry.

49. Musa AH, Vata PK, Gebru G, Mekonnen Y, Debella A, et al. (2016) Biochemical and Hematological Study on Butanol Fraction Of Leaves Of Moringa stenopetala In Experimental Rats. IOSR Journal of Pharmacy 6: 64-68.

50. Mekonnen Y, Gessesse A (1998) Documentation on the uses of Moringa stenopetala and its possible antileishmanial and ant fertility effects. SINET: Ethiopian Journal of Science 21: 287-295.

51. Geleta B, Makonnen E, Debella A, Abebe A, Fekadu N (2016c) In vitro vasodilatory activity of the Crude Extracts and Fractions of Moringa stenopetala (Baker $\mathrm{f}$.) Cufod. leaves in isolated thoracic aorta of guinea pigs. J Exp Pharmacol 8: 35-42.

52. Mussa A, Makonnen E, Urga K (2008) Effects of the crude aqueous extract and isolated fraction of Moringa stenopetala leaves in normal and diabetic mice. Pharmacologyonline 3: 1049-1055

53. Toma A, Makonnen E, Mekonnen Y, Debella A, Adis akwattana S (2015) Antidiabetic activities of aqueous ethanol and n-butanol fraction of Moringa stenopetala leaves in streptozotocin-induced diabetic rats. BMC Complementary and Alternative Medicine 15: 1.

54. Geleta B, Eyasu M, Fekadu N, Debella A, Challa F (2015a) Evaluation of Diuretic Activity of Hydro-Ethanolic Extract of Moringa stenopetala Leaves in Swiss Albino Mice. Clin Exp Pharmacol Physiol 5: 190.

55. Ghebreselassie D, Mekonnen Y, Gebru G, Ergete W, Huruy K (2011) The effects of Moringa stenopetala on blood parameters and histopathology of liver and kidney in mice. Ethiop J Health Sci 25: 51-57.

56. Geleta B, Makonnen E, Debella A (2016a) Toxicological evaluations of the crude extracts and fractions of Moringa stenopetala leaves in liver and kidney of rats. J Cytol and Histol 7: 383.

57. Musa AH, Vata PK, Debella A (2015) Acute toxicity studies of butanol fraction of leaves of Moringa stenopetala in rats. IJCMPR 1: 171-175.

58. Asfaw N, Storesund HJ, Skattebøl L, Tønnesen, F, Aasen AJ (2000) Volatile oil constituents of two Thymus species from Ethiopia. Flavour Fragr J 15: 123-125.

59. Bekele A (2016) Evaluation of the spasmolytic activity and safety of Thymus serrulatus in laboratory animals. MSc Thesis Published by Addis Ababa University 2006.

60. Geleta B, Eyasu M, Kebamo S, Debella A, Makonnen E, et al. (2015b) In vitro vasodilatory effect of aqueous leaf extract of Thymus serrulatus on thoracic aorta of Guinea pigs. Asian Pac J Trop Biomed 5: 15-18.

61. Melka AE, Makonnen E, Debella A, Fekadu N, Geleta B (2016a) Diuretic activity of aqueous crude extract and solvent fractions of Thymus serrulatus leaves in mice. Journal of Experimental Pharmacology 8: 60-67.

62. Melka AE, Makonnen E, Debella A, Fekadu N, Geleta B (2016b) Evaluation of diuretic activity of methanol extract of Thymus serrulatus leaves and its solvent fractions in mice. BLM $8: 347$.

63. Debelo N, Afework M, Debella A, Makonnen E, Ergete W, et al. (2015) Histopathological and Biochemical Assessment of Chronic Oral Administration of Aqueous Leaf Extract of Thymus serrulatus in Mice. J Clin Exp Pathol 5:258

64. Dagne E, Hailu S, Bisrat D, Worku T (1998) Constituents of the essentia oil of Thymus schimperi. Bull Chem Soc Ethiop 12: 79-82.

65. Haji H, Makonnen E, Debella A, Geleta B (2016) Evaluation of Diuretic and Antihypertensive Activity of Leaf Extracts of Thymus schimperi in Rats. BJPT 7: 1-8.

66. Tesfamaryam $\mathrm{G}$, Tsegaye $\mathrm{B}$, Eguale $\mathrm{T}$, Wubete $\mathrm{A}$ (2015) In vitro antibacterial activites of selected Ethiopian medicinal plants. IJMR 6: 27-33.

67. Damtie D, Mekonnen Y (2015) Thymus species in Ethiopia: Distribution, medicinal value, economic benefit, current status and threatening factors. EJST 8: 81-92.
68. Behailu E. Ethno botanical Study of Traditional Medicinal Plants of Goma Wereda, Jima Zone of Oromia Region, Ethiopia (2016) MSc Thesis Published by Addis Ababa University 2010.

69. Debelo N, Afework M, Debella A, Makonnen E, Ergete W (2016) Assessment of Hematological, Biochemical and Histopathological Effects of Acute and Sub-chronic Administration of the Aqueous Leaves Extract of Thymus schimperi in Rats. JCT 6: 2 .

70. Ior LD, Otimenyin IS, Umar M (2012) Anti-inflammatory and analgesic activities of the ethanolic extract of the leaf of Syzygium guineense in rats and mice. IOSR-PHR 2: 33-36.

71. Noudogbessi JP, Yédomonhan P, Sohounhloué DC, Chalchat JC, Figuérédo G (2008) Chemical composition of essential oil of Syzygium guineense (Willd.) DC. var. guineense (Myrtaceae) from Benin. REC NAT PROD 2: 33-38.

72. Maregesi S, Kagashe G, Messo C, Mugaya L (2016) Determination of Mineral Content, Cytotoxicity and Antihelmintic Activity of Syzygium guineense Fruits. Saudi J Med Pharm Sci 2: 95-99.

73. Nigatu B (2004) Antispasmodic, antidiarrheal and LD50 determination of Syzygium guineense in animal models. Master's Thesis Published by Addis Ababa University 2004.

74. Abebe D, Debela A, Urga K (2003) Medicinal plants of Ethiopia. Camerapex Publishers International: Nairobi, Kenya.

75. Loha M. Evaluation of acute and sub acute toxicity study of methano extract of Syzguim guineense leaves on the histology of the liver and kidney and biochemical compositions of the blood (2016) MSc Thesis Published by Addis Ababa University 2016.

76. Eyasu M, Shibeshi W, Gida M (2013) In vivo antimalarial activity of hydromethanolic leaf extract of Calpurnia aurea (Fabaceae) in Mice infected with chloroquine sensitive Plasmodium berghei. Int J Pharm 2: 131-142.

77. Mulata HN, Gnanasekaran N, Melaku U, Daniel S (2015) Phytochemical screening and assessment of in vitro antioxidant activities of Calpurnia aurea seeds and leaves. Int J Pharm Pharm Sci 2: 1-12.

78. Asres K, Phillipson J, Mascagni P (1986a) Two novel minor alkaloids from EthiopianCalpurnia aurea ssp. aurea. Med 4: 302-304.

79. Asres K, Willum A, David J, Mascagnlt P (1986b) Alkaloids of Ethiopian Calpurnia aureasubsp. aurea. Phytochemistry 25: 1443-1447.

80. Gebeyehu G, Asfaw Z, Eniyew A, Raja N (2014) Ethno botanical study of traditional medicinal plants and their conservation status in Mecha Wereda, West Gojjam zone of Ethiopia. Int J Pharm \& H Care Res 2: 137-154.

81. Amuamuta A and Na-Bangchang K (2015) A review of ethno pharmacology of the commonly used anti-malarial herbal agents for traditional medicine practice in Ethiopia. Afr J Pharm Pharmacol 9: 615-627.

82. Birhanu Z, Wuhab M, Abula T (2015b) Antimalarial activity of Calpurnia aurea hydroalcoholic leaf extract in mice infected with plasmodium berghei. Pharmacologyonline 2:73-79.

83. Giday M, Teklehaymanot T, Animut A, Mekonnen Y (2007) Medicinal plants of the Shinasha, Agew-awi and Amhara peoples in northwest Ethiopia. J Ethnopharmacol 110: 516-525.

84. Beemnet MK, Solomon A, Zinash TA, Haileslassie GK, Beniyam Y et al. (2011) Performance of lemongrass (Cymbopogon citratus L. (DC) Stapf) for agronomic and chemical traits in different agro-ecologies of Ethiopia. Med Aromat Plant Sci Biotechnol 5: 133-138.

85. Hailemariam GA, Emire SA (2013) Antioxidant activity and preservative effect of thyme (Thymus schimperi). Br J Appl Sci Technol 3: 1311-1326.

86. Aman BM. Metsehafe Fewus (in Amharic), Addis Ababa, Ethiopia (2015). Eleni Printing house Share Company 185-382.

87. Maryo M, Nemomissa S, Bekele T (2015) An ethno botanical study of medicinal plants of the Kembatta ethnic group in Enset-based agricultural landscape of Kembatta Tembaro (KT) Zone, Southern Ethiopia. Asian Journal of Plant Science and Research 5: 42-61. 
88. Tariku Y (2008) In vitro efficacy study of some selected medicinal plants against Leis mania spp. Doctoral Dissertation Published by Addis Ababa University 2008.

89. Geremedhin G, Karim A (2014) Cosmetic Use of Aloe Vera-a Review. WJPPS 3: 342-458.

90. Eskedar A (2011) Ethno botanical study on medicinal plants used by local communities in Debark Wereda, North Gondar Zone, Amhara Regional State, Ethiopia. Master Thesis Published by Addis Ababa University 2011.

91. Kefalew A, Asfaw Z, Kelbessa E (2015) Ethno botany of medicinal plants in Ada'a District, East Shewa Zone of Oromia regional state, Ethiopia. J Ethnobiol Ethnomed 11: 1.

92. Limenih L, Umer S, Wolde-Mariam M (2015) Ethno botanical study on traditional medicinal plants in Dega Damot Woreda, Amhara region, North Ethiopia. IJRPC 5: 258-273.

93. Keno B (1993) Kanserin Mekelakel (in Amharic), Addis Ababa, Ethiopia 172-173.

94. Alevtina G, Zerihun S (2009) Ethiopian Traditional and Herbal Medications and their Interactions with Conventional Drugs. Ethiopian Journal of Health Development 20: 127-34.

95. Daka D (2011) Antibacterial effect of garlic (Allium sativum) on Staphyloccus aureus: An ex vivo study. Afr J Biotechnol 10: 666-669.

96. Gebreyohannes G, Gebreyohannes M (2013) Medicinal values of garlic: A review. Int J Med Med Sci 5: 401-408.

97. Gidey M, Beyene T, Yirga G, Signorini AM, Bruschi P (2015) Traditional medicinal plants used by Kunama ethnic group in Northern Ethiopia. J Med Plants Res 9: 495-509.

98. Bekele T (2008) Antidiabetic activity and phytochemical screening of crude extracts of Stevia rebaudiana Bertoni and Ajuga remota Benth grown in Ethiopia on alloxan-induced diabetic mice. MSc Thesis Published by Addis Ababa University 2008.

99. Suleman S, Alemu T (2012) A survey on utilization of ethnomedicinal plants in Nekemte Town, East Wellega (Oromia), Ethiopia. J Herbs Spices Med Plants 18: 34-57.

100. Teklay A, Abera B, Giday M (2013) An ethno botanical study of medicinal plants used in Kilte Awulaelo District, Tigray Region of Ethiopia. J Ethnobiol Ethnomed 9: 1.

101. Birhanu Z, Endale A, Shewamene Z (2015) An ethno medicinal investigation of plants used by traditional healers of Gondar town, NorthWestern Ethiopia. J Med Plants 3: 36-43.

102. Girma T, Philiphos M, Abera S (2014) Profitability Study of Hibiscus sabdariffa L. Production around Wendo Genet District, Ethiopia. Science, Technology and Arts Research Journal 3: 214-218.

103. Paulos B (2012) Ethnopharmacological Survey of Medicinal Plants Among the Hammer Ethnic Group, Hammer Woreda, South Omo Zone, SNNPR, Ethiopia and Evaluation of a Selected Plant for its Anti-malarial activity. Doctoral Dissertation Published by Addis Ababa University 2012

104. Regassa R (2013) Assessment of indigenous knowledge of medicinal plant practice and mode of service delivery in Hawassa city, southern Ethiopia. J Med Plant Res 7: 517-535

105. Seid MA (2013) Medicinal and Dietary Role of Moringa stenopetala (Bak. f.) Cuf. in South Ethiopia: A Review. African Journal of Agricultural Science and Technology 1: 1-6.

106. Ambaye C, Pharm B, Tolessa T, Abera A, Sherief HT, et al. (2002) Hypotensive Activity of Residue From "Gebto Arekei", Locally Distilled Medicinal Spirit From a Brew Containing Lupinus Albus Seeds in Normotensive Guinea pigs. Ethiopian Journal of Health Sciences 12: 15-24.

107. Amsalu N (2010) An Ethinobotanical Study of Medicinal plants in Farta Woreda, South Gondar Zone of Amhara Region, Ethiopia. MSc Thesis Published by Addis Ababa University 127.

108. d'Avigdor E, Wohlmuth H, Asfaw Z, Awas T (2014) The current status of knowledge of herbal medicine and medicinal plants in Fiche, Ethiopia. J Ethnobiol Ethnomed 10: 1-32.

109. Getaneh S, Girma Z (2014) An ethnobotanical study of medicinal plants in Debre Libanos Wereda, Central Ethiopia. Afr J Plant Sci 8: 366-379.
110. Zenebe G, Zerihun M, Solomon Z (2012) An ethno botanical study of medicinal plants in Asgede Tsimbila district, Northwestern Tigray, northern Ethiopia. Ethnobotany Research and Applications 10: 305-320.

111. Etana $T$ (2007) Use and conservation of traditional medicinal plants by indigenous people in Gimbi woreda, western Wellega, Ethiopia. Master Thesis Published by Addis Ababa University 2007.

112. Yirga G (2010) Assessment of traditional medicinal plants in Endrta District, South-eastern Tigray, Northern Ethiopia. Afr J Plant Sci 4: 255-260.

113. Eshetu M (2011) Evaluation of Wound Healing Activity of Rhizomes of Rumex abyssinicus J. in Mice. Master Thesis Published by Addis Ababa University 2011.

114. Chekole G, Asfaw Z, Kelbessa E (2015) Ethno botanical study of medicinal plants in the environs of Tara-gedam and Amba remnant forests of Libo Kemkem District, northwest Ethiopia. J Ethnobiol Ethnomed 11: 4 .

115. Girma B, Yimer G, Makonnen E (2015) Effect of Rumex Abyssinicus on preneoplastic lesions in dimethylhydrazine induced colon carcinogenesis in rats. BMC Complementary and Alternative Medicine 15: 365.

116. Mulisa E, Asres K, Engidawork E (2015) Evaluation of wound healing and anti-inflammatory activity of the rhizomes of Rumex abyssinicus J. (Polygonaceae) in mice. BMC Complementary and Alternative Medicine 15: 341 .

117. Eshetu A (2007) Diuretic Efficacy evaluation of crude extracts and fractions of Thymus serrulatus. Master Thesis Published by Addis Ababa University 2007.

118. Parvez N, Yadav S (2010) Ethno pharmacology of single herbal preparations of medicinal plants in Asendabo district, Jimma, Ethiopia. Indian Journal of Traditional Knowledge 9: 724-729.

119. Meragiaw M, Asfaw Z, Argaw M (2016) The status of ethno botanical knowledge of medicinal plants and the impacts of resettlement in Delanta, northwestern Wello, northern Ethiopia. Evidence-Based Complementary and Alternative Medicine 5060247: 1-24.

120. Wassie SM, Aragie LL, Taye BW, Mekonnen LB (2015) Knowledge, Attitude, and Utilization of Traditional Medicine among the Communities of Merawi Town, Northwest Ethiopia: A Cross-Sectional Study. Evidence-Based Complementary and Alternative Medicine 138073: 1-7.

121. Berhan A, Asfaw Z, Kelbessa E (2006) Ethno botany of plants used as insecticides, repellents and antimalarial agents in Jabitehnan district, West Gojam. SINET: Ethiopian Journal of Science 29: 87-92.

122. Mesfin F, Seta T, Assefa A (2014) An ethnobotanical study of medicinal plants in Amaro Woreda, Ethiopia. Ethnobotany Research and Applications 12: 341-354.

123. Megersa M, Asfaw Z, Kelbessa E, Beyene A, Woldeab B (2013) An ethno botanical study of medicinal plants in Wayu Tuka district, East Welega zone of Oromia Regional State, West Ethiopia. J Ethnobiol Ethnomed 9: 68.

124. Sintayehu T (2011) An Ethnobotanical study of medicinal plants in Wondo Genet natural forest and adjacent Kebeles, Sidama zone, SNNP region, Ethiopia. Doctoral Dissertation Published by Addis Ababa University 2011.

125. Abiyu E, Zemede A, Ensermu K, Raja N (2014) Ethno botanical study of traditional medicinal plants in and around Fiche District. Central Ethiopia. Current Research Journal of Biological Sciences 6: 154-167.

126. Umer S, Tekewe A, Kebede N (2013) Antidiarrhoeal and antimicrobial activity of Calpurnia aurea leaf extract. BMC Complementary and Alternative Medicine 13: 21.

127. Kuru M, Adugna G, Berecha G (2016) The importance of avocado (Persea americana Mill.) fruits anthracnose and factors influencing the disease in Mana district, south-western Ethiopia. Archives of Phytopathology and Plant Protection 49: 157-166.

128. Wabe NT, Mohammed MA, Raju NJ (2011) An ethnobotanical survey of medicinal plants in the Southeast Ethiopia used in traditional medicine. Spatula DD 1: 153-158. 
Citation: Meresa A, Fekadu N, Degu S, Tadele A, Geleta B (2017) An Ethno Botanical Review on Medicinal Plants Used for the Management of Hypertension. Clin Exp Pharmacol 7: 228. doi:10.4172/2161-1459.1000228

Page 16 of 16

129. Alemayehu G, Asfaw Z, Kelbessa E (2015) Ethno botanical study of medicinal plants used by local communities of Minjar-Shenkora District, North Shewa Zone of Amhara Region, Ethiopia. J Med Plant 3: 01-11.

130. Tadesse M, Hunde D, Getachew Y (2005) Survey of medicinal plants used to treat human diseases in Seka Cherkosa, Jimma Zone, Ethiopia. Ethiopian Journal of Health Sciences 15: 89-106.

131. Desta B (1995) Ethiopian traditional herbal drugs. Part I: Studies on the toxicity and therapeutic activity of local taenicidal medications. J Ethnopharmacol 45: 27-33.

132. Abayneh E (2014) The effect of Psidium guava leaf extract on blood pressure in guinea pigs, and weight, lipid profiles and serum liver enzymes in fructose fed swiss albino mice. MSc Thesis Published by Addis Ababa University 2014.

133. Yadav RH (2013) Medicinal plants in folk medicine system of Ethiopia. Journal of Poisonous and Medicinal Plants Research 1: 7-11.

134. Teklehaymanot T, Giday M (2007) Ethnobotanical study of medicinal plants used by people in Zegie Peninsula, northwestern Ethiopia. J Ethnobiol Ethnomed 3: 12.
135. Asressu KH (2013) Antimicrobial activity and phytochemical screening of crude extracts of medicinal plants grown in eastern Ethiopia. Int J Pharm Biosci 4: 326-333.

136. Eshete MA, Kelbessa E, Dalle G (2016) Ethno botanical study of medicinal plants in Guji Agro-pastoralists, Blue Hora District of Borana Zone, Oromia Region, Ethiopia. J Med Plant 4: 170-184.

137. Araya S, Abera B, Giday M (2015) Study of plants traditionally used in public and animal health management in Seharti Samre District, Southern Tigray, Ethiopia. J Ethnobiol Ethnomed 11: 22.

138. Teklehaymanot $\mathrm{T}$ (2009) Ethno botanical study of knowledge and medicinal plants use by the people in Dek Island in Ethiopia. J Ethnopharmacol 124: 69-78.

139. Wolde T, Engidawork E, Asres K, Eregete W (2010) Evaluation of Hepatoprotective Activities of Satureja punctata Benth Briq and Solanecio angulatus Vahl Jeffrey in Ferric Nitrillotriacetate Induced Hepatotoxicity in Rats. Ethiopian Pharmaceut J 28: 63-74. 